\title{
Food security and food quality among vanilla farmers in Madagascar: the role of contract farming and livestock keeping
}

\author{
Jessica Noromalala Andriamparany ${ }^{1}$ (D) $\cdot$ Hendrik Hänke $^{2}$ (D) $\cdot$ Eva Schlecht $^{1}$ (D)
}

Received: 31 May 2020 / Accepted: 14 February 2021 / Published online: 12 May 2021

(C) The Author(s) 2021

\begin{abstract}
The northeastern SAVA region of Madagascar is the largest vanilla producing area in the world and is flourishing due to a large global demand for natural vanilla. Although the general socio-economic situation has regionally improved because of high vanilla prices, little is known about the nutritional status of local vanilla farmers. We used a 12-month longitudinal food survey to analyze food security, food consumption and nutrient intake of local vanilla farming households $(n=140)$. Food consumption data was complemented with baseline, agro-economic, longitudinal and field-plot information to determine factors influencing food security, and the contribution of protein from Animal Source Food (ASF_protein) to household nutrition using a stepwise generalized linear model. Results show a high level (74\%) of food insecurity and micronutrient deficiency but an acceptable level of protein intake among surveyed households. Consumption of rice, the principal source of carbohydrates, is stable across the year. Compared to other regions in Madagascar, local diets are moderately diversified with an acceptable share of ASF_protein (about 50\%). Household size $(P<0.001)$ and cash income from rice sales $(P<0.001)$ were the most important factors influencing the food security index (FSI), while cash crop income $(P<0.01)$ and number of income sources $(P<0.01)$ were more important in the explanation of the dietary share of ASF_protein. Yet, neither livestock ownership nor contracting with vanilla buyers/ exporters did improve food security of the surveyed households. Households who concluded contracts were significantly less food secure than non-contracting households $(P=0.01)$ with seasonal fluctuations across the year. Policy implications of our findings are that, although many actors of the vanilla value chain run social and environmental programs in the SAVA region, more needs to be done to improve diet quality at household level and strengthen farmers' resilience to food insecurity.
\end{abstract}

Keywords Animal source food $\cdot$ Dietary diversity $\cdot$ Food security index $\cdot$ Seasonality $\cdot$ Vanilla farmers

\section{Introduction}

In developing countries, the cultivation of cash crops is seen as a key strategy by governments and development agencies to improve food security both at the state as well as the farm household (HH) level (Achterbosch et al. 2014). Income generated through cash crop provides farming HHs a means to save and invest in a more productive farm operation, improves

Jessica Noromalala Andriamparany

jessica.andriamparany@agr.uni.goettingen.de

1 Animal Husbandry in the Tropics and Subtropics, University of Kassel and Georg-August-Universität Göttingen,

Albrecht-Thaer-Weg 3, 37075 Göttingen, Germany

2 Research Unit Environmental and Resource Economics, Department of Agricultural Economics and Rural Development,

Georg-August-Universität Göttingen, Platz der Göttinger Sieben 5, 37073 Göttingen, Germany access to food and HHs' food security (Achterbosch et al. 2014).

Madagascar's northeastern (NE) SAVA region is the largest vanilla (Vanilla planifolia Jacks. ex Andrews) producing area in the world. Since around 2014, rising global demand for natural vanilla has led to high vanilla prices of which local farmers benefit (Hänke et al. 2018, in review; Hänke and Fairtrade International 2019). In fact, prices of cured, black vanilla have increased from less than US\$50 to US\$600 between 2012 and 2018 (Cooks Vanilla 2019; Appendix Fig. 9). Likewise, the share of socially and environmentally certified vanilla is rapidly increasing and many companies and NGOs established sustainability programs in the region, which include formal education of children, price premiums, support in income diversification, and rural development programs (Hänke et al. 2018, in review; Hänke and Fairtrade International 2019). Recent surveys show that the general socio-economic situation has improved, e.g. in terms of income, vanilla prices received, education of children, and 
access to electricity (Hänke et al. 2018, in review; Save The Children 2019; Symrise 2018; Unilever 2016). In terms of food security, the SAVA region performs better than other regions in Madagascar, even though malnutrition is still common here. Estimations show that 40 to $60 \%$ of the children suffer from anemia, underweight and stunting, due to deficient diets and low food quality (USAID Madagascar 2018; WFP 2016). Recent studies also indicate that not all vanilla farming HHs have equally benefitted from the vanilla boom, partly due to high inflation of local food and living costs (Hänke and Fairtrade International 2019; Llopis et al. 2020). Also, many vanilla farming HHs reallocate labor to secure vanilla fields as there is high theft pressure (Hänke et al. 2018, in review; Neimark et al. 2019).

Livelihood diversification, e.g. through livestock production - in addition to cropping - has been shown to improve well-being (Barrett et al. 2001; Harvey et al. 2014; Neudert et al. 2015), increase resilience to shocks, and serve as insurance for smallholders in periods of (cash) crop failure (Hänke and Barkmann 2017). Although the contribution of animal husbandry to income diversification in the SAVA region is so-far limited (Kunz et al. 2020), it might have the potential to enhance $\mathrm{HH}$ food security through the access to fat, protein, vitamins and minerals, and as a source of high-quality food for children (Adesogan et al. 2020). In fact, animal source food (ASF) has been hypothesized to have beneficial effects on child growth (Pimpin et al. 2019), and a recent meta-analysis by Adesogan et al. (2020) showed that increasing per capita consumption of meat leads to a decrease of the proportion of stunted children in many countries across the world. In this respect, the World Health Organization states that ASF are vital to sustainability in middle to low income countries, where diets are heavily based on starchy foods; likewise, ASF play a critical role in improving nutrition, food security, health, and livelihoods and reducing poverty (WHO 2014).

Contract farming has been identified as another option to enhance local food security (Mishra et al. 2018; Soullier and Moustier 2018). With respect to the vanilla value chain in Madagascar, a recent survey showed that in 2019 about 20\% of all vanilla farmers in the SAVA region were contracted with vanilla business partners, i.e., exporters, collectors or preparators (Hänke and Fairtrade International 2019). Such contracts are used to certify vanilla farmers, for example through Rainforest Alliance, Fairtrade or Organic labels. Contracting leads to a substantial shift in the vanilla value chain with respect to farm-gate prices received, implementation of sustainability programs and direct support for vanilla farmers. Such factors might enhance the food security of local farming HHs through better access to and/or affordability of food. However, little is known about HHs' food security and food quality in the region, and in particular if the vanilla boom, as well as contracting schemes, have improved food security and nutritional status of the local farming population.

In this contribution we assess the (i) food consumption, food quality and food security of local vanilla farming $\mathrm{HHs}$ using a high-resolution longitudinal food survey. We mainly look at the seasonal variation in food consumption and nutrient intakes, undernourishment levels, dietary diversity, and the dietary share of protein from domestic animal source food (ASF_protein). We analyze (ii) factors determining food security and intake of ASF protein by combining the food survey with other data sources, namely baseline, market and agro-economic surveys that covered the same HHs. We thereby hypothesize that (1) the higher the income from vanilla sales, the higher a HH's food security; (2) vanilla farmers with diversified income generating activities are more food-secure than specialized HHs; (3) HHs engaged in livestock production consume a higher share of ASF_protein than HHs not keeping animals.

\section{Materials and methods}

\subsection{Study area and sampling design}

The SAVA region lies in tropical NE Madagascar and is the largest vanilla producing area in the world (SVI 2019). Its name is an abbreviation of the districts Sambava, Antalaha, Vohemar and Andapa (see Fig. 1) that constitute the region. The area experiences a humid-tropical climate with an average annual temperature of $24.7{ }^{\circ} \mathrm{C}$ and an average yearly precipitation of $2409 \mathrm{~mm}$ (Weather Sparks 2020). The rainy season falls between December and April. The majority of the population $(91 \%)$ are famers but raising livestock is also common, with $71 \%$ of HHs owning chicken and $43 \%$ owning zebus (Hänke et al. 2018, in review). However, livestock production is weakly professionalized (Kunz et al. 2020). Vanilla is by far the most important cash crop in the region and $83 \%$ of the HHs practice vanilla farming, but there are also other cash crops such as cloves, pepper, coffee, cocoa as well as rice (ibid). Subsistence crops mainly include rice, tubers (yams, cassava and sweet potato), and beans and pulses. Tropical fruits such as mangos, jackfruit, litchis and pineapple are abundant but only seasonally available. In the SAVA region, food availability is seasonal due to only one rainy season. The lean season typically occurs from January to April, yet, local farmers hardly stock rice and other foods as annual production is often insufficient (Hänke and Fairtrade International 2019; FAO et al. 2019). During the lean season food prices can increase considerably on local markets (Hänke and Fairtrade International 2019).

The study was embedded in the Diversity Turn research project (https://www.uni-goettingen.de/en/529181.html), which focuses on the vertical integration of vanilla farmers through contracts/certification schemes as well as 


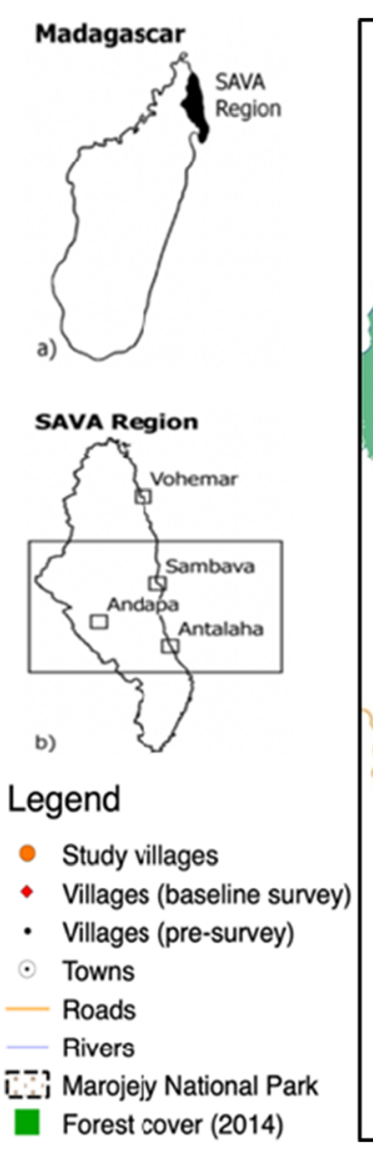

Fig. 1 Study area within the SAVA region, NE Madagascar, showing the 60 villages where the baseline survey was conducted (Hänke et al. 2018, in review), and the 14 villages selected for the food consumption survey.

on social diversity and poverty (Hänke et al. 2018, in review). In 2016, key informant interviews were conducted to define the core vanilla growing area within the SAVA region, also called the "vanilla triangle" (Fig. 1). From this region most vanilla is sourced and a high prevalence of contract farming arrangements (CFAs) between vanilla buyers and farmers were found, usually complemented by certification schemes such as Fairtrade, Organic, Rainforest Alliance and others (Hänke et al. 2018, in review). Within the vanilla triangle, selection of sample villages and HHs for the Diversity Turn Baseline Survey (DTBS, $n=1800$ HHs, Hänke et al. 2018, in review) was based on a stratified random approach accounting for an even distribution of differently sized villages $(n=60)$ across the region. Due to logistic constraints, the limit of the study area was set to villages located at maximum $10 \mathrm{~km}$ away from primary (paved) and secondary (nonpaved) roads so that all villages were accessible within one day from Sambava, Andapa or Antalaha (Hänke et al. 2018, in review; Fig. 1). Comparing the pre-survey data by Hänke et al. (2018, in review) to official data (CREAM 2014) and latest election lists used in Hänke et al. (2018, in review), it was estimated that about 10 to
Sources: Forest cover: Vieilledent et al. (2018); Road, rivers and boundaries: World Bank (2010); Marojejy National Park: UNEP-WCMC and IUCN (2018)

$20 \%$ of the regional population was excluded by this sampling strategy (Kunz et al. 2020).

The present food consumption survey was based on a subsample of $140 \mathrm{HHs}$ from the DTBS sample, likewise selected according to a stratified random approach. First, one village from each of five village-size strata was selected, for villages with and without vanilla contracts, respectively. In each of the 10 villages ( 5 contracted 5 non-contracted), 14 vanilla growing $\mathrm{HHs}$ were randomly selected from lists that we received (Appendix Table 4, see Hänke et al. 2018, in review for more details). In consequence, the following groups were distinguished in this study:

- Contracted HHs: Contracted HHs are those having a contract with a collector, exporter or another business partner, usually with trading conditions beyond spot markets;

- Non-contracted HHs: Non-contracted HHs do not have any contract and mostly depend on the informal vanilla spot market (Hänke et al. 2018, in review).

In addition, the Multidimensional Poverty Index (MPI) was calculated for the HHs, which covers three dimensions: education, health and living standard. The MPI takes a value 
between 0 and 1 , and a $\mathrm{HH}$ is defined as multidimensionally (MD) poor if its MPI is $\leq 0.33$ (Alkire et al. 2014, see Table 1).

\subsection{Food consumption survey}

\subsubsection{Household food consumption survey}

To assess the food security and consumption of the local vanilla farming households, we captured food groups and quantities that HHs consumed over a 12-month period (July 2018 June 2019) through a longitudinal food survey $(n=140)$. To this end, pictograms of food groups were designed with the support of a local arts teacher. They represented different food items expressed in local units and were grouped as follows (Appendix Table 5): cereals (rice, maize), tubers (yams, sweet potatoes and cassava), pulses (beans, peas, lentils), vegetables (carrots, tomatoes, onions), fruits (mainly jackfruit, mangoes, litchis, pineapple), beef, pork, chicken, other poultry, milk, yogurt, eggs, bush meat (mainly lemur, wild pig), wild poultry (birds, guinea fowl), fish and crustaceans, and luxury beverages (beer and sodas). The survey had a pre-test phase of 4 weeks and a final feedback round with the participating
HHs in June 2018 before the start of the survey. Food groups that were rarely mentioned or consumed in very small amounts, such as oil, fat, and sugar were not included in the final pictograms. Also food groups of little nutritional value such as sweets, condiments and spices are often excluded in the calculation of alternative dietary diversity indicators (cf. Sibhatu and Qaim 2017) and were thus ignored.

Throughout the 12-month survey period, printout tables with the pictograms were filled in by the participants over one full week ( 7 days) per month to capture daily but also monthly food consumption of the entire $\mathrm{HH}$ (food items and quantities consumed). Thus, per household, food consumption data of 84 full days was acquired during the 12-month period. Dietary requirements (in $\mathrm{kcal}$ ) were calculated for each $\mathrm{HH}$ (based on age group and gender of each $\mathrm{HH}$ member, as recorded in the DTBL.

To estimate quantitative consumption, the following locally common units were used: kilograms for fish and meat, kapoky (a pot of $100 \mathrm{ml}$ ) for rice, beans and peas, and pieces for tubers, vegetables, fruits, fish and eggs. The filled-in forms were collected bi-weekly by four research assistants and one supervisor, and data was entered into a database using tablet

Table 1 Composition of the households $(n=104)$ covered by the 12-month food consumption survey in the SAVA region, north-eastern Madagascar

\begin{tabular}{|c|c|c|c|c|}
\hline \multicolumn{3}{|l|}{ Variable } & Mean & SD \\
\hline \multicolumn{3}{|c|}{ Household size (n) } & 5.25 & 2.44 \\
\hline \multicolumn{3}{|c|}{ Age HH head (years) } & 49.58 & 13.09 \\
\hline \multicolumn{3}{|c|}{ Years of schooling, HH head } & 6.28 & 3.85 \\
\hline \multicolumn{3}{|c|}{ Men_equal/older_18 (n) } & 1.33 & 0.57 \\
\hline \multicolumn{3}{|c|}{ Women_equal/older_18 (n) } & 1.21 & 0.49 \\
\hline \multicolumn{3}{|c|}{ Boys_younger_18 (n) } & 1.32 & 0.56 \\
\hline \multicolumn{3}{|c|}{ Girls_younger_18 (n) } & 0.72 & 0.34 \\
\hline \multicolumn{3}{|c|}{ Full time adult equivalents (FTE, $n)^{*}$} & 2.54 & 1.13 \\
\hline \multicolumn{3}{|c|}{ Multidimensional Poverty Index (MPI) characteristics } & $\begin{array}{l}\% \text { in } \\
\text { sample }\end{array}$ & $\begin{array}{l}\text { Relative } \\
\text { weight }\end{array}$ \\
\hline \multirow[t]{2}{*}{ Education } & $\begin{array}{l}\text { Years of } \\
\text { schooling }\end{array}$ & No household member has completed five years of schooling. & 15.10 & $1 / 6$ \\
\hline & $\begin{array}{l}\text { Child school } \\
\text { attendance }\end{array}$ & Any school-aged child is not attending school up to the age at which they would have to. & 7.50 & $1 / 6$ \\
\hline \multirow[t]{2}{*}{ Health } & Child mortality & Any child has died in the household. & 8.30 & $1 / 6$ \\
\hline & Nutrition* & Any adult or child, for whom there is nutritional information, is malnourished. & $*$ & $1 / 6$ \\
\hline \multirow{6}{*}{$\begin{array}{l}\text { Living } \\
\text { standard }\end{array}$} & Electricity & The household has no electricity at home. & 35.19 & $1 / 18$ \\
\hline & $\begin{array}{l}\text { Improved } \\
\text { sanitation }\end{array}$ & $\begin{array}{l}\text { The household's sanitation facility is not improved (according to MDG guidelines), } \\
\text { or is improved but shared with other households. }\end{array}$ & 66.70 & $1 / 18$ \\
\hline & $\begin{array}{l}\text { Safe drinking } \\
\text { water }\end{array}$ & $\begin{array}{l}\text { The household does not have access to safe drinking water (according to MDG guidelines), } \\
\text { or safe drinking water is more than a } 30 \text {-min roundtrip walk from home. }\end{array}$ & 0.00 & $1 / 18$ \\
\hline & Flooring & The household has a dirt, sand or dung floor. & 79.60 & $1 / 18$ \\
\hline & Cooking fuel & The household cooks with dung, wood or charcoal. & 100.00 & $1 / 18$ \\
\hline & Assets & $\begin{array}{l}\text { The household does not own more than one radio, TV, telephone, bike, motorbike, } \\
\text { refrigerator, and does not own a car or truck. }\end{array}$ & 32.40 & $1 / 18$ \\
\hline
\end{tabular}

(*) Full time adult equivalent is the number of active members engaged in agricultural activities in the household, who, depending on age and activity, are converted to full-time work equivalents according to ILO (2011) 
computers. Local units were subsequently converted to standardized units (kilogram, liter) using locally established conversion factors (Hänke and Fairtrade International 2019).

\subsubsection{Food seasonality survey}

To establish a comprehensive list of all food items consumed and their availability throughout the year (Fig. 2), a complementing survey on food seasonality was conducted between July and September 2019. In three different zones of the study region (Andapa, Sambava and Antalaha, see Fig. 1), 10 HHs each were asked to list all food items that were previously depicted as food groups in the pictograms and their seasonal availability. The three zones were selected such that the different microclimatic zones within the SAVA region were represented (UPDR 2003). In addition, the harvesting period of important crops (paddy rice, upland rice, vanilla) was also discussed to serve as reference for the seasonal food calendar. The official vanilla harvest dates are set by the local government and depend on the blooming of vanilla plants. The vanilla harvest dates differ by not more than four weeks between
Sambava, Antalaha and Andapa. However, due to high risk of theft of vanilla from the plantations, many farmers harvest their vanilla immature (Hänke et al. 2018, in review).

\subsection{Food security and dietary indicators}

Given the multidimensional nature of food security, practitioners and policy makers have recognized the need for a variety of means to measure it (FAO 2013). The main aim of this study was to assess the food security, the diet quality and the amount of calories, protein and vitamins consumed by the local vanilla farming HHs. For this, a variety of food security indicators were used: Household Food Security Index (FSI) was used to determine the food security status of a household; Household Dietary Diversity Score (HDDS) was used to determine the ability of a household to access a variety of foods (in a snapshot form); Food Consumption Score (FCS) was used to capture the usual food consumption of the $\mathrm{HH}$; nutrient intakes were calculated to better understand the implications of the various indicators for actual consumption of specific macro and micronutrients.

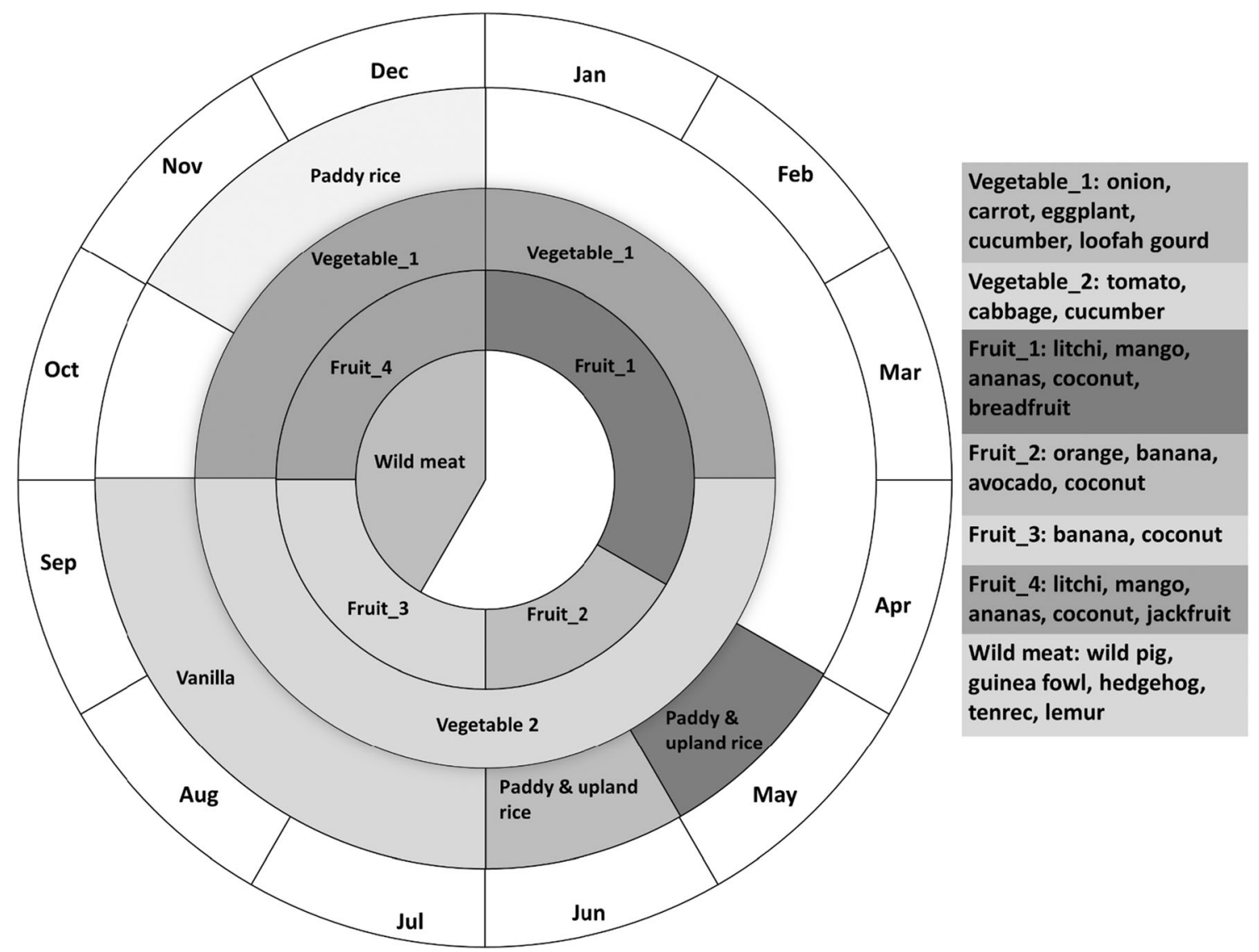

Fig. 2 Seasonal availability of selected food groups (showing only frequently consumed foods in each season), harvest of paddy rice, upland rice, and vanilla in the SAVA region, NE Madagascar, as determined in a food seasonality survey in 2019 


\subsubsection{Food security index (FSI) and nutrient intake}

To estimate a HH's food security index (FSI), the mean caloric energy intake of each $\mathrm{HH}$ was calculated as follows (Etea et al. 2019; Noromiarilanto et al. 2016):

$F S I_{\mathrm{i}}=Y_{\mathrm{i}} / E_{\mathrm{i}}$

where $F S I_{\mathrm{i}}$ is the food security index of the $i$-th $\mathrm{HH}$ which is $\geq 1$ for a "food secure" $\mathrm{HH}$ and takes a value $<1$ for a "food insecure" $\mathrm{HH} . \mathrm{Y}_{\mathrm{i}}$ is the daily calorie intake of $i$-th $\mathrm{HH}$ and $\mathrm{E} i$ is the daily calorie requirement of the i-th $\mathrm{HH}$. The actual daily $\mathrm{HH}$ calorie supply was estimated based on $\mathrm{HH}$ consumption data. The recommended daily calorie intake in Madagascar is 2133 kcal per capita (FAO and UPDR 2000). Given the different calorie requirements of different $\mathrm{HH}$ members, the latter were clustered into three gender and age groups and the average daily calorie requirements of each group were converted into adult equivalents (Appendix Table 6).

The daily $\mathrm{HH}$ calorie requirement (Ei) was calculated as:

$E_{\mathrm{i}}=N_{\mathrm{i}} \times R$

where $\mathrm{N}_{\mathrm{i}}$ represents the total number of persons in $i$-th $\mathrm{HH}$ converted into adult equivalents (Table 2), and $\mathrm{R}$ is the recommended daily calorie intake. To assess the food security per $\mathrm{HH}$, mean FSI values were calculated per $\mathrm{HH}$ for the sampled period.

In order to calculate nutrient intake, we created lists of the nutrient composition (Appendix Table 7) of all foods including: energy, protein, fat, carbohydrates, vitamin A and vitamin E using existing online food composition tables, FAO Food Balance Sheets and other relevant studies (FPSRAG 2015; Golden et al. 2019; Leung 1968; MacLean and Warwick
2003). If we were unable to retrieve precise information on a specific food, e.g. local varieties of beans or wild meat, a weighted average of nutrient values from similar foods was used (based on the same references). Furthermore, we combined results of our seasonal food survey with food consumption data to derive the season-specific nutrient intake. Finally, a HH's nutrient intake was calculated by multiplying the daily food quantities consumed $(\mathrm{kg})$ with their nutritional values (in $\mathrm{kcal}, \mathrm{g}, \mathrm{mg}$ or $\mu \mathrm{g}$ per $\mathrm{kg}$ ).

To assess the share of protein intake from domestic ASF, the average protein content of the food groups of domestic meat (beef and pork), poultry, dairy products (milk and yogurt), and eggs was summed up and the share of ASF protein calculated as percentage of the total amount of protein consumed by the HH (Workicho et al. 2016).

\subsubsection{Household dietary diversity score (HDDS) and food consumption score (FCS)}

Diet diversity indicators, such as Household Dietary Diversity Score (HDDS) and Food Consumption Score (FCS), are often used to indicate food security in terms of both availability and access to food at the HH level (Headey and Ecker 2013; Ruel 2003). They are considered as a qualitative measure of food consumption that reflects household access to a variety of foods, and also serve as proxy for nutrient adequacy of the diet of individuals. While validation studies have demonstrated that FCS and HDDS are highly correlated, they can be used interchangeably as a measure of household-level diet diversity (HDDS) and as a validated proxy for energy sufficiency (Maxwell et al. 2013).

HDDS measures the number of food groups consumed by the $\mathrm{HH}$ and categorizes food items into the following 12

Table 2 Results from pairwise-t-test of selected socioeconomic and food security indicators between contracted and non-contracted vanilla farming households in the SAVA region, north-eastern Madagascar

\begin{tabular}{|c|c|c|c|c|c|c|c|}
\hline \multirow[t]{3}{*}{ Parameters } & & \multicolumn{4}{|c|}{ Group of vanilla farming households } & \multicolumn{2}{|l|}{ t-Test } \\
\hline & & \multicolumn{2}{|l|}{ Contracted } & \multicolumn{2}{|c|}{ Non-contracted } & \multirow[t]{2}{*}{ t-value } & \multirow[t]{2}{*}{$\mathrm{p}$ value } \\
\hline & & Mean & SD & Mean & $\mathrm{SD}$ & & \\
\hline \multirow[t]{4}{*}{ Socio-economic } & TLU & 0.47 & 0.62 & 0.81 & 1.30 & -1.308 & 0.201 \\
\hline & Vanilla income (MGA) & $4,868,300$ & $6,288,065$ & $2,316,450$ & $6,488,584$ & 1.750 & 0.091 \\
\hline & Income from rice sales (MGA) & 96,183 & 148,984 & 293,133 & 580,259 & -1.761 & 0.089 \\
\hline & MPI & 0.25 & 0.09 & 0.24 & 0.07 & 0.758 & 0.455 \\
\hline \multirow[t]{4}{*}{ Food security indicators } & FSI & 0.64 & 0.22 & 0.83 & 0.33 & -2.682 & 0.012 \\
\hline & HDDS & 6.86 & 0.58 & 6.86 & 0.56 & 0.047 & 0.963 \\
\hline & FCS & 44.29 & 5.26 & 45.31 & 4.91 & -0.88 & 0.384 \\
\hline & Protein_ASF & 45.22 & 9.30 & 45.63 & 7.58 & -0.20 & 0.840 \\
\hline
\end{tabular}

Abbreviations: TLU $=$ Tropical Livestock Unit, FSI=Household Food Security Index, HDDS=Household Dietary Diversity Score, FCS=Food Consumption Score, Protein_ASF = share of protein from Animal Source Foods, MPI = Multidimensional Poverty Index, MGA = Malagasy Ariary 
groups (FAO 2011): cereals, roots and tubers, pulses, vegetables, fruits, meat, dairy products, eggs, fish, beverages, sugar and sweets, oils and fat (Appendix Table 8). In our calculation of HDDS per sampling period of 7 days, we used 10 food groups excluding sugar and sweets as well as oils and fat. HDDS was calculated as follows: a HH that consumed a given food group at least once a week was scored as 1, irrespective of consumption frequency, and HDDS was constructed as the sum of numbers of food groups consumed per week. In the current sample, the minimum and maximum HDDS were 1 and 10, respectively. A higher score indicates higher diet diversity, as more food groups were consumed. The scores were used to define three diversity categories with HDDS $<4.5$ representing "low dietary diversity", 4.5 to 6 "medium dietary diversity" and $>6$ "good dietary diversity" (Wiesmann et al. 2009).

Food Consumption Score (FCS) was computed by using slightly different categories (Appendix Table 8) and applying weights to the "nutrient density" of each of the following seven food groups (food weight in parenthesis): vegetables (1); fruits (1); staples (2); pulses (3), meat, fish and eggs (4); dairy products (4); sugar (0.5). The food group of oils and fats (0.5) was not sampled in our food survey. The FCS was calculated by multiplying the amount of days in a week that a $\mathrm{HH}$ consumed a given food group by the food group's weight, and finally summing these values. Generally, FCS can range from 0 to 112 , whereby scores of $\leq 21$ are considered "poor", scores between 21.5 and 35 are "borderline" and score of $>35$ are "acceptable" (Vhurumuku 2014).

\subsection{Covariates}

Data used in this study originate predominantly from the longitudinal food consumption survey. However, we also incorporated information from other surveys that were conducted with the same HHs:

\subsubsection{Diversity turn baseline survey (DTBS)}

The DTBS (Hänke et al. 2018, in review, $n=1800$ ) served as a preliminary overview of $\mathrm{HH}$ involvement in cash- and subsistence cropping as well as livestock keeping. Moreover, the survey covered a range of socio-economic variables such as $\mathrm{HH}$ size, years that the HH head was living in the village, age and education level of the $\mathrm{HH}$ head, income sources, existence of a vanilla contract, livestock ownership and other variables that were used in the present study. The livestock ownership variable, Tropical Livestock Unit (TLU), was calculated as the total number of livestock owned by the $\mathrm{HH}$, using the following livestock conversion factors: one zebu $=0.7$, one goat $/$ sheep $=0.1$, one pig $=0.20$ and one poultry $=0.01$ (Jahnke et al. 1988).

\subsubsection{Longitudinal agro-economic survey and recall survey}

The longitudinal survey (Andrianisaina et al. forthcoming, $n=140$ ) was conducted between September 2017 and September 2018. Here, tables with pictograms were filled in daily by the respondents and collected bi-weekly by research assistants. Parameters included were:

a) Household labour input concerning all vanilla-related agricultural activities;

b) Income from vanilla (green and black), rice (income from rice sales only, home consumption not included) and vegetable production;

c) Income from cash crops other than vanilla (e.g. coffee, cocoa, cloves, ginger);

d) Income from non-timber forest products (NTFPs: honey, medicinal plants, wild fruits);

e) Expenditures for health and education.

The recall survey $(n=140)$ was conducted between January and March 2019 and covered some of the variables included in the longitudinal survey but also included questions on changes in the HH structure over time, on vanilla sales, vanilla theft, harvest of other crops, other income sources and agricultural inputs used for vanilla and rice production.

\subsubsection{Field survey and measurements}

Rice and vanilla plot sizes of $140 \mathrm{HHs}$ were measured in-situ using GPS devices during June to August 2019. To do this, farmers walked together with research assistants along the borders of the respective fields. In addition, self-reported harvests of vanilla and rice in the year 2018 were collected through a semi-structured questionnaire.

\subsection{Statistical analysis}

Data was firstly cleaned by identifying and removing invalid data points and extreme outliers that might bias the results. Statistical analyses were performed in R.3.6.0. (R Core Team 2013). We computed stepwise generalized linear models, using the model fitting glmulti package (Calcagno and de Mazancourt 2010), in order to analyze the influence of socio-economic factors on $\mathrm{HH}$ food security and the share of ASF_protein in the diet. Glmulti package is an automated model selection tool, building all possible models and analyzing their possible pairwise interactions (Calcagno and de Mazancourt 2010). Akaike Information Criteria (AIC) was used to select the best model during the procedure of "forward and backward steps" and the threshold of each factor on the model was set at $\alpha=<0.05$. Prior to the analysis, we explored the distribution, variability and correlation between all food security indicators used in this study. In the final food security 
models, only share of ASF_protein and FSI were selected because they represent the qualitative (ASF_protein) and quantitative (FSI) dimensions of food security. Also, FSI is essentially based on calorie intake, while the share of ASF_protein can be used as a proxy measure of diet quality (INDEEX Project 2018). As our datasets were large, we used a linear data reduction technique, namely Principal Component Analysis (PCA), to avoid multicollinearity between the explanatory variables (cf. Naser and Peel 1998). Thereby, similar variables were grouped and those with higher Eigenvalue were selected for the subsequent analysis (Appendix Table 9).

In addition, a pairwise t-test was conducted to compare socioeconomic parameters (MPI, vanilla income, rice income, number of livestock) and food security indicators between contracted HHs and non-contracted HHs. Moreover, a time series analysis was conducted so as to capture the seasonal changes and trends over time of FSI and the share of ASF_protein in diets, thereby comparing contracted $\mathrm{HHs}$ and non-contracted $\mathrm{HHs}$ by using ARIMA models within R software package "fpp2 "(R Core Team 2013). To do this, data was arranged as time series of seven days per month spread over a 12-month period (i.e. 84 time points).

\section{Results}

\subsection{Household characteristics}

The composition of the sampled HHs from 10 different villages in 4 districts is shown in Table 3. After cleaning and merging the different data sources used, the final sample size was 104. The average HH size (Mean $\pm \mathrm{SD}$ ) was 5.2 \pm 2.4 members and most HHs were headed by a male (79.2\%). The mean age of the HH head was 49.6 years. Concerning the parameters used to construct the Multidimensional Poverty Index (MPI, see Table 1), around $7.5 \%$ of schoolaged children were not attending school and $8.3 \%$ of the surveyed $\mathrm{HHs}$ reported that at least one child had died in early infancy. About $35 \%$ of the surveyed HHs did not have electricity at home, but the majority $(67.6 \%)$ owned more than one of the following assets - radio, TV, telephone, bicycle, motorbike. All HHs used wood as cooking fuel and $79.6 \%$ of the

Table 3 Results of the stepwise generalized linear model for the dependent variables food security index (FSI) and share of protein supplied by domestic animals (ASF_protein) in the diet (average of 12 months) of 104 households in the SAVA region, north-eastern Madagascar*

\begin{tabular}{|c|c|c|c|c|c|c|c|c|}
\hline \multirow[b]{2}{*}{ Coefficients } & \multicolumn{4}{|l|}{ FSI } & \multicolumn{4}{|c|}{ Share of ASF_protein in diet } \\
\hline & Estimate & SE & t-value & $\mathrm{p}$ value & Estimate & SE & t-value & $\mathrm{p}$ value \\
\hline (Intercept) & 1.07 & 0.08 & 12.95 & $<0.001$ & 0.38 & 4.27 & 8.91 & $<0.001$ \\
\hline Vanilla contract & -0.07 & 0.03 & -1.92 & 0.05 & - & - & - & - \\
\hline HH size & -0.07 & 0.01 & -9.50 & $<0.001$ & 0.29 & 0.32 & 0.91 & 0.358 \\
\hline Age of HH head & 0.01 & 0.01 & 0.90 & 0.321 & 0.02 & 0.07 & 0.31 & 0.752 \\
\hline Rice income & $1.7\left(10^{-7}\right)$ & $0.4\left(10^{-7}\right)$ & 4.04 & $<0.001$ & - & - & - & \\
\hline $\begin{array}{l}\text { Wild meat } \\
\text { consumption }\end{array}$ & -0.54 & 0.03 & -1.53 & 0.12 & - & - & - & - \\
\hline $\begin{array}{l}\text { Number of income } \\
\text { sources }\end{array}$ & - & - & - & - & 1.06 & 0.34 & 3.12 & $<0.01$ \\
\hline Cash income & - & - & - & - & $2.9\left(10^{-5}\right)$ & $0.95\left(10^{-5}\right)$ & 3.10 & $<0.01$ \\
\hline Rice harvest & - & - & - & - & 0.01 & 0.01 & 0.59 & 0.555 \\
\hline Field size & & & & & 1.295 & 1.17 & 1.11 & 0.272 \\
\hline Model & \multicolumn{4}{|c|}{ FSI $\sim 1+$ V_con + HH_size $+\mathrm{HHH} \_$age + R_INC + W_meat } & \multicolumn{4}{|c|}{$\begin{array}{l}\text { ASF_protein } \sim 1+\mathrm{HH} \_ \text {size }+\mathrm{HHH} \_ \text {age }+\mathrm{N} \_\mathrm{REV}+\mathrm{C} \_\mathrm{INC}+\mathrm{R} \_\mathrm{HRV} \\
+ \text { Field_size }\end{array}$} \\
\hline Log Likelihood & \multicolumn{4}{|l|}{39.35} & \multicolumn{4}{|c|}{-259.20} \\
\hline AIC & \multicolumn{4}{|l|}{-63.44} & \multicolumn{4}{|l|}{536.46} \\
\hline BIC & \multicolumn{4}{|l|}{-46.76} & \multicolumn{4}{|l|}{553.36} \\
\hline Model (Sig.) & \multicolumn{4}{|l|}{$<0.001$} & \multicolumn{4}{|l|}{0.003} \\
\hline
\end{tabular}

Best model selection was based on AI criterion; Abbreviations: ASF (animal source food; in this table, only food from livestock is included in ASF, while wild meat is treated as independent variable), V_con (vanilla contract), HH_size (household size), HHH_age (age of household head), R_INC (rice income), W_meat (wild meat), N_REV (number of income sources, C_INC (cash income other than vanilla), R_HRV (rice harvest in "daba", a local unit with 1 daba $\approx 15.24 \mathrm{~kg}$ ), V (vanilla), Field_size (combined size of all fields of the HH in ha). Monetary unit: all income factors are expressed in Malagasy Ariary

*This table does not attempt to compare "FSI" and "Share of ASF protein" since both represent different dimensions of food security and were also calculated differently (see methods part) 
surveyed HHs did not have a cemented floor in their home (Table 1).

\subsection{Household food security and seasonal trend}

The average food security index of the sampled HHs (Mean \pm $\mathrm{SD})$ was $0.77 \pm 0.27$. The recommended daily calorie intake per capita (see Section 2.3.2: $2133 \mathrm{kcal} \mathrm{day}^{-1}$ ) was only met by $26 \%$ of the HHs with a mean FSI of $1.14 \pm 0.19$. With an average FSI of $0.65 \pm 0.19$, the remaining $74 \%$ of the HHs did not meet this threshold value.

Looking at seasonal patterns of the FSI across all sampled HHs (Fig. 3), there were decreases in FSI around AugustOctober, in January and March with lowest average FSI value of 0.70. Ignoring the small drop in March, FSI peaked from November to April with an average of 0.86 for all HHs, whereby highest FSI values coincided with the rainy season and paddy rice harvest (Fig. 2).

When comparing food security parameters between contracted and non-contracted $\mathrm{HHs}$, the contracted $\mathrm{HHs}$ were found to be less food secure $(P=0.012)$ than the noncontracted ones (Table 2). Concerning the socioeconomic parameters, contracted $\mathrm{HHs}$ had, on average, more vanilla income but less rice income, and owned less livestock than non-contracted HHs; however, no statistical significant differences existed between the two groups for these variables.

The results of the time series analysis (Fig. 4 and Appendix Table 10) showed the presence of stationary (i.e. regular) seasonal fluctuations every four months (number of lags $=4$ for all models), especially for FSI models. Although all models presented seasonal fluctuations, none of them depicted a decisive trend (i.e. neither an increase nor a decrease over time, Mann-Kendall-test $P>0.05$ for all variables). The time series

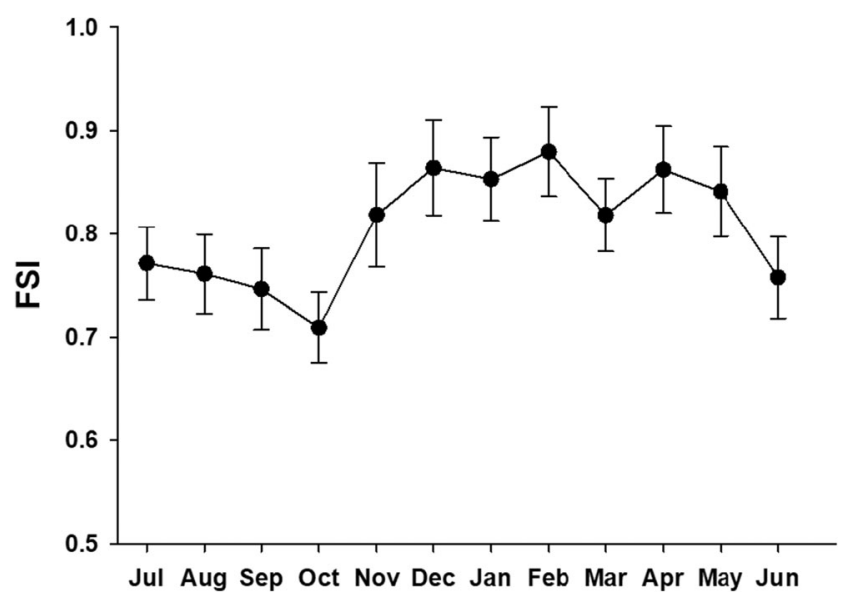

Fig. 3 Monthly variation of the average food security index (FSI) of 104 households included in the food security survey in the SAVA region, NE Madagascar (July 2018-June 2019). Dots depict monthly means, error bars depict one SE plots (Fig. 4 and Appendix Fig. 10) indicate that seasonal changes in FSI were slightly more pronounced for contracted HHs than for non-contracted ones. Concerning the share of ASF protein, both $\mathrm{HH}$ groups showed strong seasonal fluctuations but again without decisive trends.

\subsection{Household nutrient intake}

Nutrient compositions were used to calculate the average energy and nutrient intake across the sampled period (Fig. 5). The average daily energy intake for all $\mathrm{HHs}$ was $1717.26 \pm 876.89 \mathrm{kcal} \mathrm{d}^{-1}$ per adult equivalent and the pattern showed a trend similar to the FSI, with two lows occurring in October $\left(1522.13 \mathrm{kcal} \mathrm{d}^{-1}\right.$ capita $\left.^{-1}\right)$ and in March $\left(1744.73 \mathrm{kcal} \mathrm{d}^{-1}\right.$ capita $\left.^{-1}\right)$. The highest energy intake values were found in December, February and April, with an average of $1852.28 \mathrm{kcal} \mathrm{d}^{-1}$ capita $^{-1}$. This trend was, however, not prevalent in the intake of carbohydrates (average intake of all HHs: $236.07 \pm 14.59 \mathrm{~g} \mathrm{~d}^{-1}$ capita $^{-1}$ ), where a sharp drop in intake was found in December $\left(206.98 \mathrm{~g} \mathrm{~d}^{-1}\right.$ capita $^{-1}$ ) compared to the rest of the year, with the highest values occurring in July (254.16 $\mathrm{g} \mathrm{d}^{-1}$ capita $^{-1}$ ). Cereals (mainly rice) provided about $57 \%$ of the total energy consumed, and $68 \%$ if combined with roots and tubers (mainly cassava and yams). Approximately $26 \%$ of the total energy intake originated from domestic ASF.

The daily total protein intake, expressed in grams per day per person (average for all HHs: $79.77 \pm 8.71$ ) did not present huge variations across the year, except that peaks occurred in February and in April (95.15 and 89.80, respectively). About 50\% of the total protein intake came from domestic ASF, with an overall average of $40.32 \pm 6.12 \mathrm{~g} \mathrm{~d}^{-1}$ capita $^{-1}$. The second most important source of protein was fish (11.9\%), whereas bush meat provided less than $1 \%$ of total protein intake in the study period.

The intake of fat $\left(46.32 \pm 6.10 \mathrm{~g} \mathrm{~d}^{-1}\right.$ capita $\left.^{-1}\right)$ did not show a particular trend but a sudden increase of fat intake occurred in December $\left(71.63 \mathrm{~g} \mathrm{~d}^{-1}\right.$ capita $\left.^{-1}\right)$. In contrast to this, vitamin A and vitamin E intake ( $302 \pm 60.42 \mu \mathrm{g} \mathrm{d}^{-1}$ capita $^{-1}$ and 4.75 $\pm 0.84 \mathrm{mg} \mathrm{d}^{-1}$ capita $^{-1}$ ) varied greatly across the year with different patterns as compared to FSI, energy and protein intake (Fig. 5b). While the variation of vitamin A consumption was more pronounced than that of vitamin $\mathrm{E}$, the highest peak for both appeared between November and December $\left(402.33 \mu \mathrm{g} \mathrm{d}^{-1}\right.$ capita $^{-1}$ and $6.21 \mathrm{mg} \mathrm{d}^{-1}$ capita $^{-1}$ ) and the lowest values were found in October $\left(190.31 \mathrm{\mu g} \mathrm{d}^{-1}\right.$ capita $^{-1}$ and $3.75 \mathrm{mg} \mathrm{d}^{-1}$ capita $^{-1}$ ).

\subsection{Household dietary diversity and seasonal variation of food consumption}

Across the ten relevant food groups, HDDS ranged from 4.9 to 9.0 , with a mean HDDS of $6.92 \pm 0.7$ and little variation throughout the year (Fig. 6). Of all $\mathrm{HHs}$, 96.7\% 

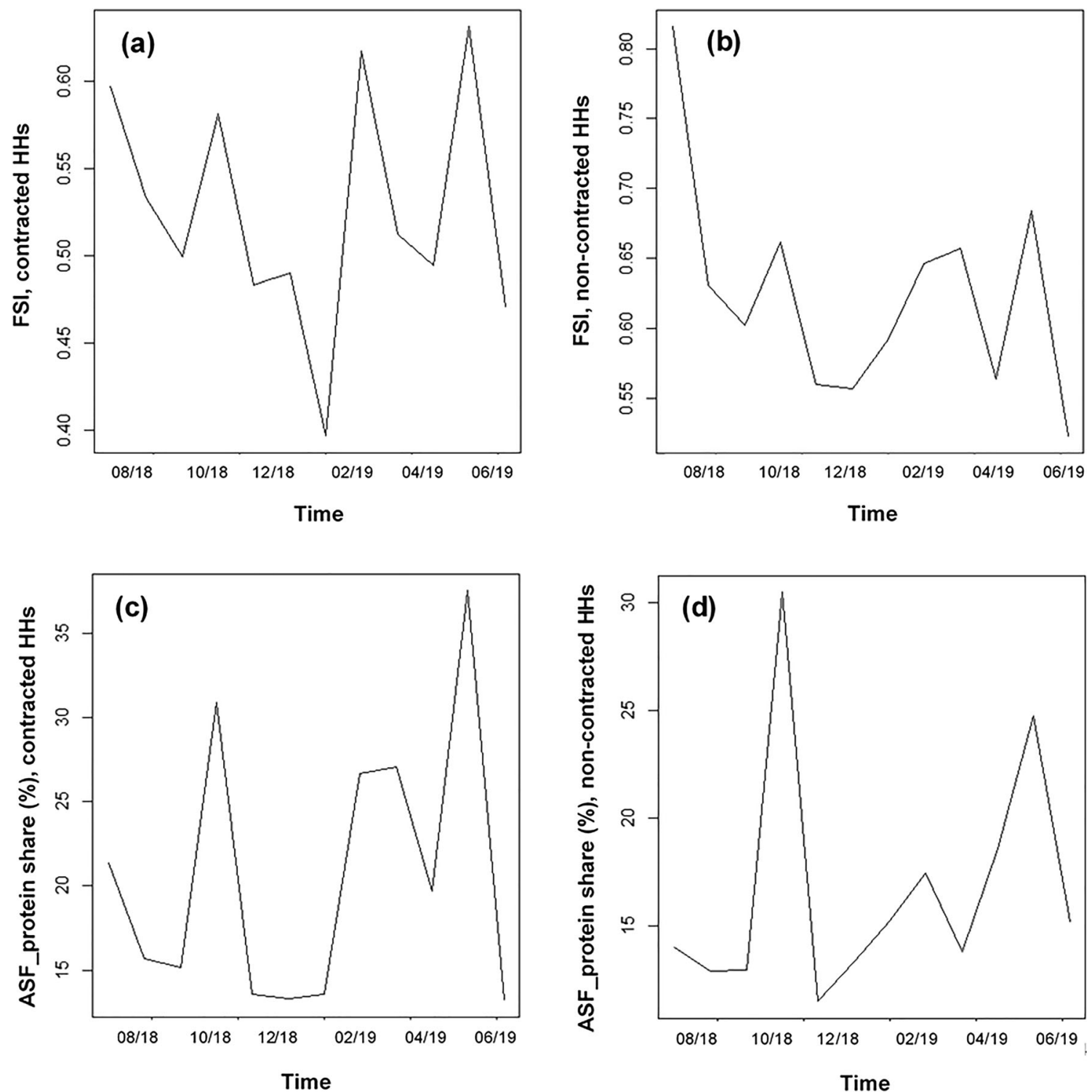

Fig. 4 Time series plots for contracted households $(\mathrm{a}=\mathrm{FSI}, \mathrm{c}=$ share of ASF protein $)$ and non-contracted households $(b=F S I, d=$ share of ASF protein) in NE Madagascar during a 12-month period (July 2018-June

had a HDDS $>6$ and thus a good dietary diversity (see Section 2.3.2). FCS ranged from 27 to 75 (46.2 \pm 6.9 ), with 97.5\% of the sampled HHs showing an acceptable food consumption. FCS showed a more pronounced seasonal variation than HDDS, with a peak in December and lowest values in March and October.

The seasonal variation of the averaged weekly frequency of consumption of food groups is presented in Fig. 7. Rice was consumed daily throughout the year (6.9 times per week on average) while roots and tubers were consumed 1.2 times per week, on average. Domestic ASF were consumed 3 times a week, whereby meat was the most

frequently (1.6 times) and dairy (0.5 times) the least frequently consumed ASF. Bush meat was consumed less than once a week (0.06) and the least frequently consumed food group. Rice consumption was stable throughout the seasons, whereas the consumption of fruits and vegetables dropped substantially in March and in October, with highest frequencies recorded at the end of the year (November-December), that is, during the rainy season when fruits are abundant (Fig. 2). Almost all food groups followed this trend but differed in the degree of variation. An exception were roots and tubers of which consumption peaked in July and was low in November-December.

2019). ASF: animal source food; FSI: Food Security Index; HHs: households; Time on $\mathrm{x}$-axes is expressed as month/year 

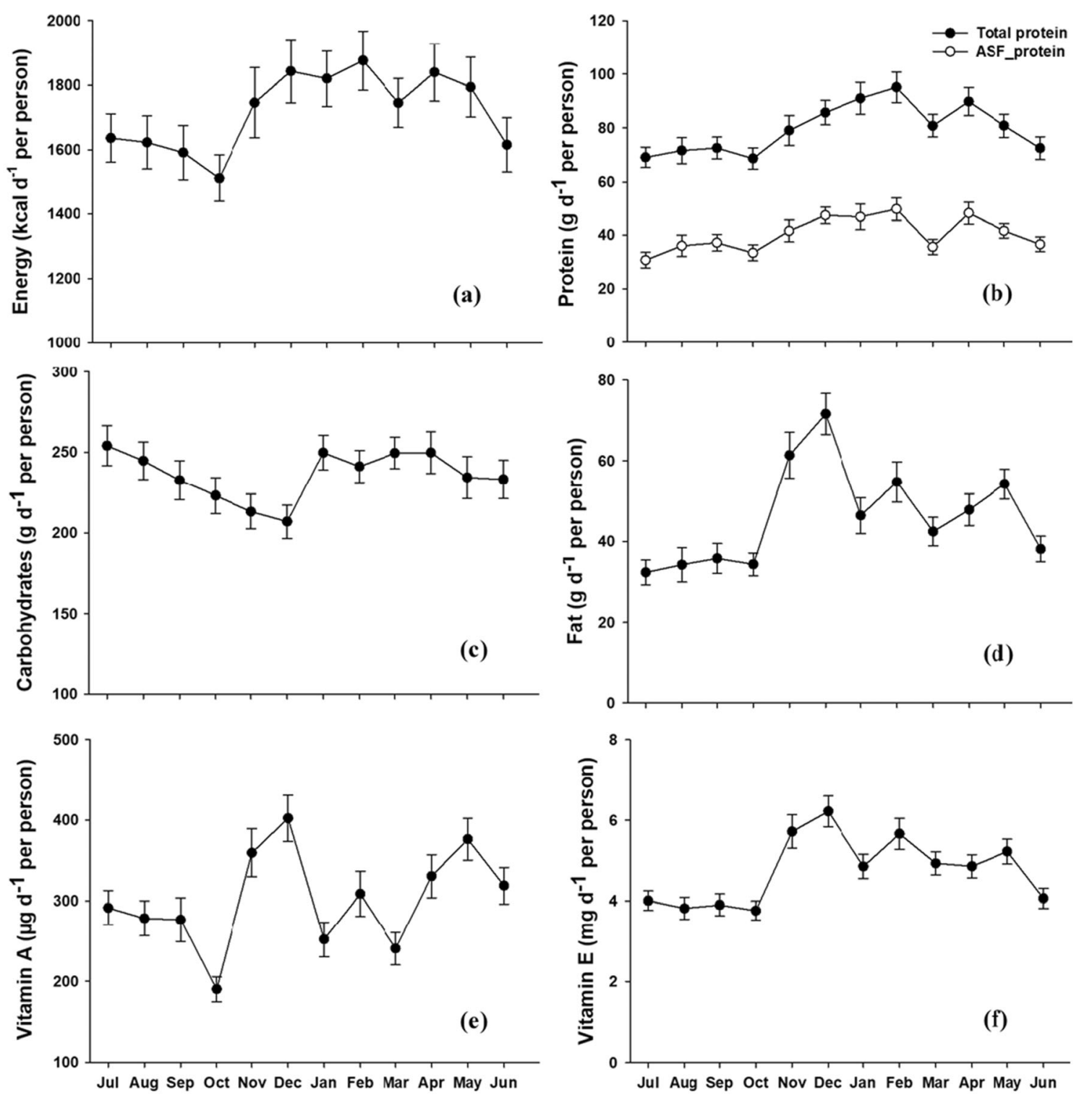

Fig. 5 Seasonal variation of the daily intake of (a) energy, (b) protein, (c) carbohydrates, (d) fat, (e) vitamin A, and (f) vitamin E per person (July 2018-June 2019) as determined in the food consumption survey with $\mathrm{n}=$

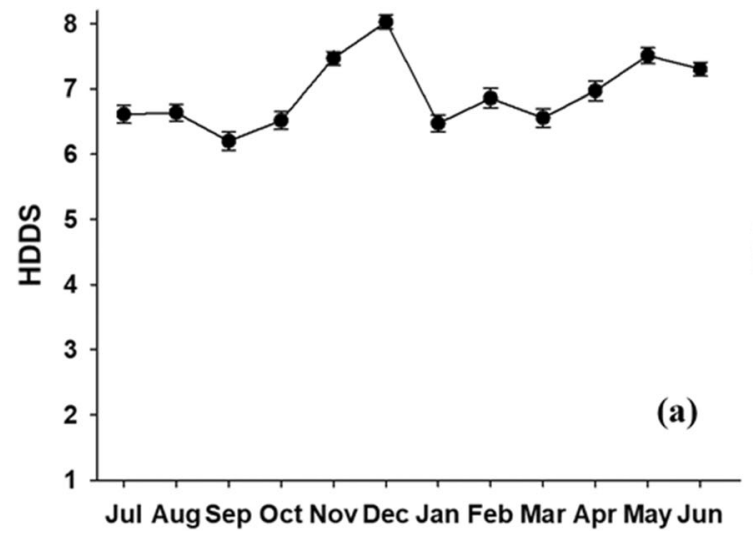

104 households in the SAVA region, NE Madagascar. Dots depict monthly means; error bars depict one SE; please note the different scaling of y-axes

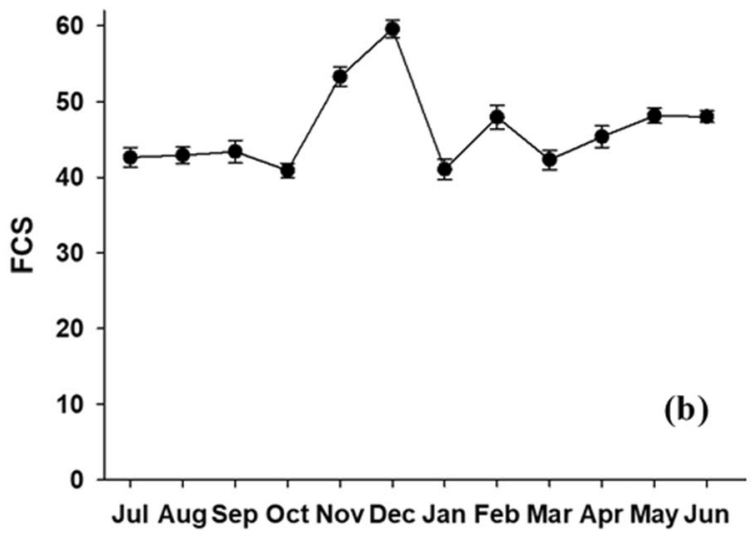

Fig. 6 Seasonal variation of (a) Household Dietary Diversity Score (HDDS) and (b) Food Consumption Score (FCS) of 104 households covered by the food consumption survey in the SAVA region, NE

Madagascar (July 2018-June 2019). Dots depict monthly means; error bars depict one SE; please note the different scaling of $y$-axes 
Fig. 7 Weekly frequency of consumption of major food groups (a) Cereal, Fruits \& vegetables, Pulses, Roots and tubers, and (b) Domestic ASF, Fish, Wild meat, by 104 households covered by the food consumption survey (July 2018June 2019) in the SAVA region, NE Madagascar. ASF: animal source food
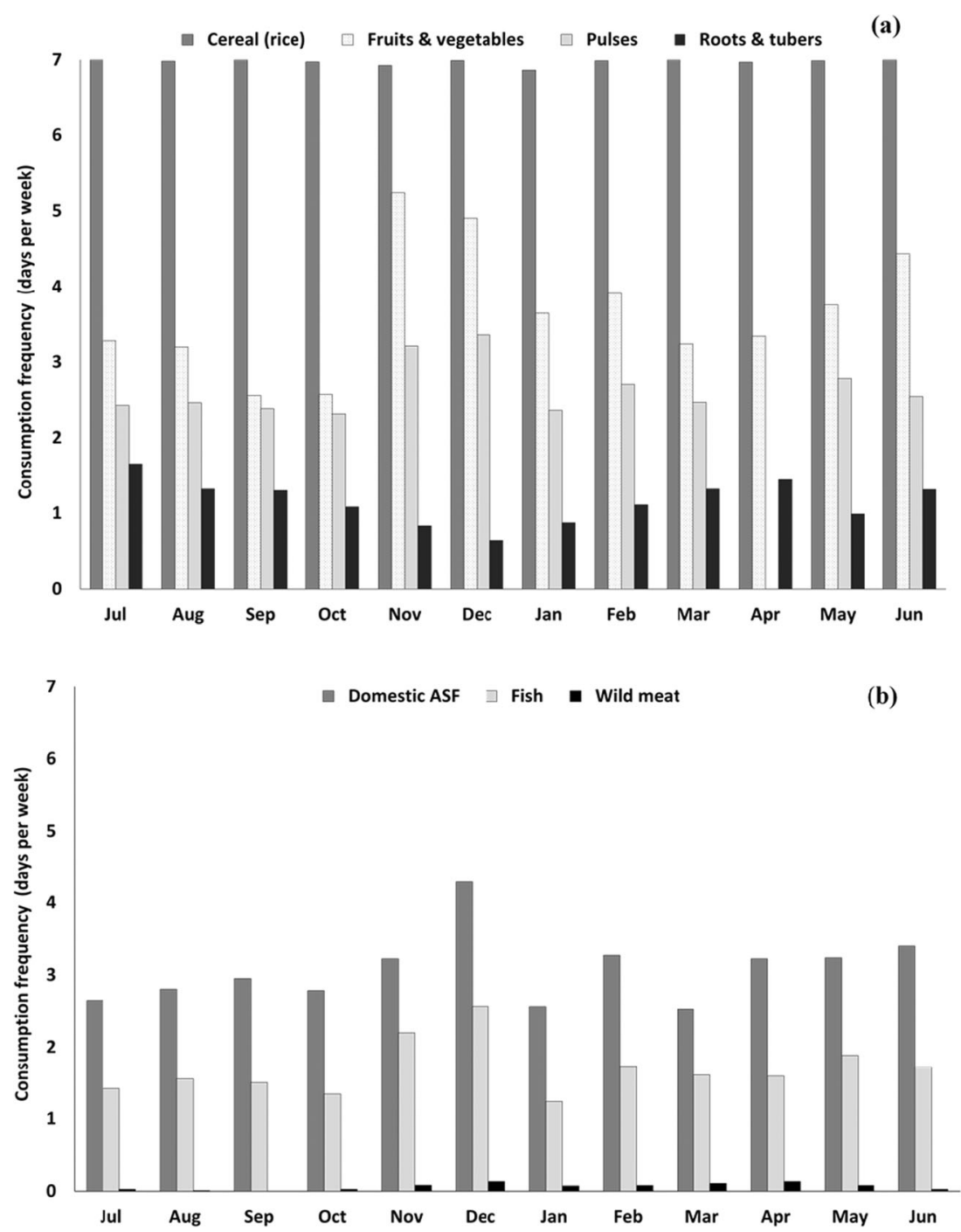

\subsection{Factors influencing household food security and share of ASF_protein in diets}

Table 3 presents the results of the stepwise generalized linear model (SGLM) for the food security index (FSI) and protein intake from domestic animals (ASF protein).

The overall significance of the AIC selected models was $P<0.001$ for FSI and $P=0.003$ for the protein contribution of ASF. HH size $(P<0.001)$ and cash income from rice sales $(P<0.001)$ were the most significant factors influencing FSI of vanilla farming $\mathrm{HHs}$, with smaller $\mathrm{HHs}$ and $\mathrm{HH}$ with higher cash from rice being more food secure. Equally, number of income sources other than vanilla $(P<0.01)$ and cash-crop income other than vanilla $(P<0.01)$ significantly increased the share of ASF protein intake in consumed foods. Having a vanilla contract was negatively associated with FSI $(P=0.05)$. The number of tropical livestock units (TLU) a HH possessed was not selected in the final SGLMs, neither for FSI nor for ASF_protein share. Still, the relative importance of this and other variables for each model is presented in Fig. 8.

\section{Discussion}

Our results suggest that despite the current high vanilla prices, the majority of vanilla farmers in the SAVA region struggle in terms of food security and adequate food quality. During the survey period, their daily food intake was insufficient, particularly in terms of energy, vitamin A and vitamin E, low in terms of fat but sufficient in terms of protein and carbohydrates (largely from rice). However, neither the possession of livestock nor concluding a contract with vanilla buyers/ exporters significantly improved vanilla farmers' food security. However, our results suggest that smaller HHs, HHs with multiple income sources, and HHs who could sell rice surpluses and cash crops other than vanilla were significantly more food secure (FSI) and had an improved diet quality (share of 

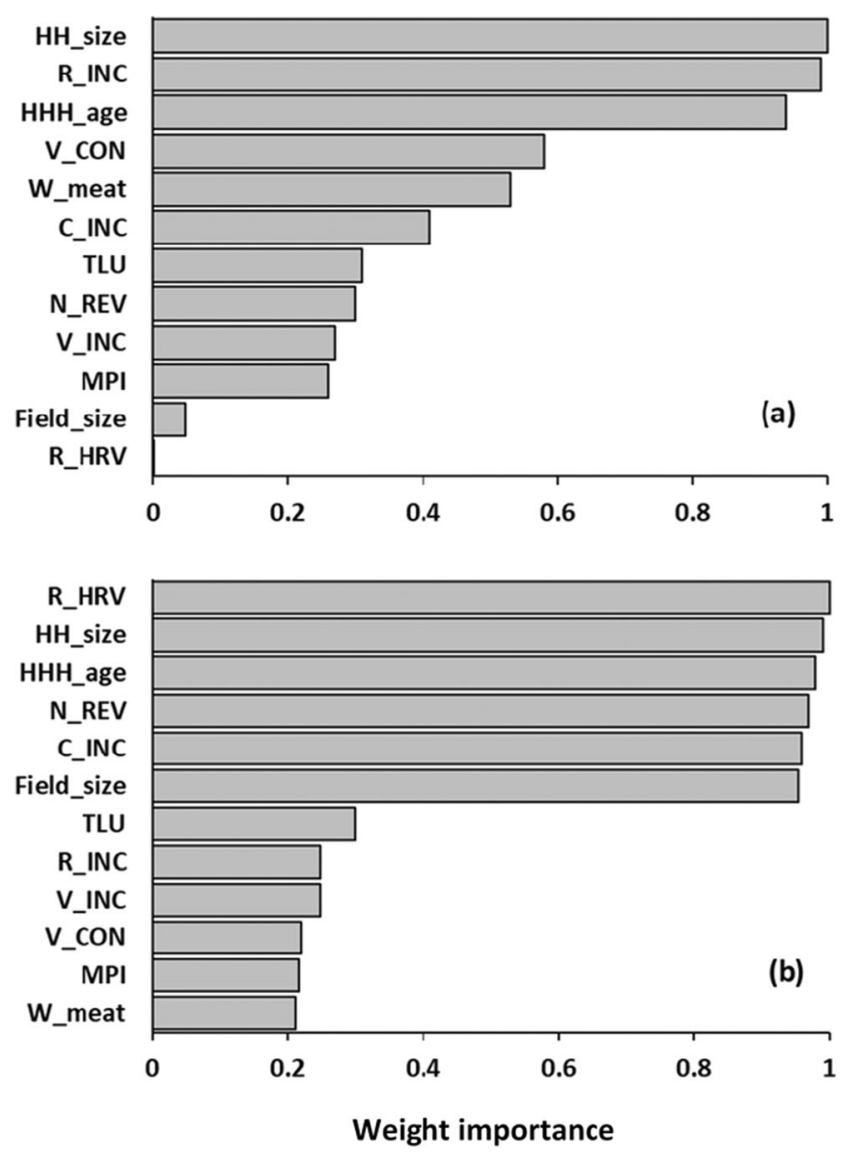

Fig. 8 Model-averaged importance of independent variables tested in the FSI-model (a) and in the ASF_protein model (b). Variables with a great weight receive a high importance value for the model. Abbreviations: HH_size (household size), R_INC (cash income from rice sales), HHH_age (age of household head), V_CON (vanilla contract), W_meat (wild meat), C_INC (cash crop income other than vanilla), TLU (tropical livestock unit), N_REV (number of income sources), V_INC (vanilla income), MPI (multi-dimensional poverty index), Field_size (combined size of all fields of the HH in ha), R_HRV (rice harvest in "daba", a local unit with 1 daba $\approx 15.24 \mathrm{~kg}$ ). Monetary unit: all income factors are expressed in Malagasy Ariary (MGA)

ASF protein in the consumed food). The nutritional status of the majority of our sampled HHs was in fact unsatisfactory, whereby the different indicators used revealed different facets of the HHs' food consumption, which are discussed in the following.

\subsection{Food security status}

Despite the vanilla boom, the large majority of smallholder vanilla farmers in the SAVA region were not able to provide sufficient food for their families. The analysis of food security indicators revealed that the $\mathrm{FAO} / \mathrm{WHO}$ recommended minimum daily energy intake was not met by $74 \%$ of the sampled HHs. Nevertheless, the HHs had a relatively diversified portfolio of food items and an acceptable food consumption level, based on HDDS thresholds (FAO 2011) and FCS thresholds (WFP 2008). Diets were dominated by cereals (rice), with a low consumption of fat-rich and nutrient-dense food groups.

The level of undernutrition that we determined here is similar to what the National Nutrition Office (ONN) modelled for the overall SAVA region, where $80 \%$ of all HHs could not meet the staple-adjusted nutritious diet threshold in 2016 (WFP and ONN 2016). On the other hand, a study by Assefa (2018), conducted in six regions of Madagascar, found that $88.7 \%$ of all Malagasy HHs were food insecure, which is a higher share than the rate of food insecurity for our surveyed HHs. The sampled vanilla farmers might be slightly more food secure than HHs in other regions of Madagascar because of relatively high cash earnings during the current vanilla boom. Indeed, as is detailed below (Section 4.4), cash earning predicts food security and protein intake.

As far as the dietary diversity indicators are concerned, the HHs' average FCS was higher than the mean FCS reported for the SAVA region in 2011 (WFP and UNICEF 2011) and for other parts of NE Madagascar (Golden et al. 2019). On a national level, the average FCS determined in the present study is similar to the FCS reported for the "food secure" group of Malagasy HHs (WFP 2009). According to the WFP (2009), the "food secure" HHs had a higher purchasing power than other HHs, which is also the case for the vanilla producing HHs in the SAVA region. However, living costs, and particularly food prices, are currently much higher in the SAVA region than in other parts of Madagascar (Hänke and Fairtrade International 2019; Wageindicator 2020). Moreover, while most food security studies report that the Malagasy diet is characterized by a low energy intake and is poorly diversified, the mean HDDS of our sample HHs suggests satisfactory dietary diversity. Yet, since dietary diversity reflects a snapshot of the economic ability of HHs to access a variety of foods (FAO 2011), the current vanilla price boom may only provide temporal superiority of local vanilla farming $\mathrm{HHs}$ compared with "average Malagasy HHs".

On the other hand, although the dietary diversity indicators for the vanilla farming HHs (HDDS, FCS) pointed to a better situation than in other parts of Madagascar, when comparing results across studies one needs to pay attention to the different approaches used (e.g. recall period, construction of the index) for measuring dietary diversity (FAO 2011; Kennedy et al. 2011). In the current study, HDDS was computed as the mean weekly HDDS across a period of 12 months and was based on 10 food groups. Due to the humid-tropical climate of the SAVA region, diverse foods are available on markets (Save The Children 2015), and many crops are grown, intercropped or mixed with staple and cash crops (Hänke et al. 2018, in review; Zaehringer et al. 2015). However, they are highly seasonal (see Fig. 5) and access to food goes beyond food availability, since factors such as lack of assets, purchasing power and food prices are also relevant (Burchi and de Muro 2016). Also, dietary diversity indicators are often 
used to take a rapid time-sensitive decision (e.g. targeting food rations in emergency situations). For this reason, they are often criticized as being oversimplified and hiding important nutritional details of the diets (Jones et al. 2013; Ruel et al. 2012). Therefore, other indicators such as nutrient intakes were also computed in the present study.

Overall, results obtained for the various food security indicators (FSI vs HDDS and FCS) are partly contradictory; this is not unusual since they measure different aspects of food security (cf. Hirvonen et al. 2016; Huang et al. 2015). The proportion of food secure people measured by FSI was much lower than that measured by FCS and derived from the proportion of HHs considered to have a diverse diet (HDDS), which underlines the need for applying various indicators to capture different dimensions of food security (Coates 2013; FAO 1996).

\subsection{Nutritional status and diet quality}

The survey revealed an insufficient intake of calories, a high intake of carbohydrates (rice), a sufficient intake of protein, a low fat and a very low vitamin A and $\mathrm{E}$ intake of the respondent HHs. This is in agreement with what can be expected for typical Malagasy diets (Ravaoarisoa et al. 2018, Shiratori and Nishide 2018). Indeed, one of the major hunger challenges identified by the Malagasy government and NGOs are the poor nutritional characteristics of Malagasy diets (WFP 2019).

Still, the average nutrient intake by the sampled $\mathrm{HHs}$ was slightly higher than values reported from other regions of Madagascar. For instance, although a generally low energy intake was determined in our study as well as in another study from NE Madagascar (Golden et al. 2019), the average energy intake of $1717 \mathrm{kcal} \mathrm{d}^{-1}$ per person was higher than the $1426 \mathrm{kcal}$ $\mathrm{d}^{-1}$ reported by Golden et al. (2019). A possible reason is that the study of Golden et al. (2019) was conducted at the edge of the Makira National Park, with a weak transport infrastructure, while our $\mathrm{HHs}$ were sampled at maximum $10 \mathrm{~km}$ away from main or dirt roads. Although vanilla and other cash crops (coffee, cloves, cocoa, pepper) are also produced in other parts of NE Madagascar, the SAVA region has a better local infrastructure and the location of our sampled HHs provided them better access to markets and thus to a higher variety of foods.

Moreover, the share $(68 \%)$ of starchy foods (roots, tubers and rice) in the food consumed by the studied HHs was lower than the $80 \%$ share reported for entire Madagascar (Arimond et al. 2011). This indicates an improved diet when considering the $\mathrm{WHO} / \mathrm{FAO}$ recommended $55-75 \%$ share of carbohydrates for nutritional balance (WHO and FAO 2003). Since the sampled households were situated within the "vanilla triangle" where most of Madagascar's vanilla is produced, the improved intake of calories and carbohydrates might be a result of vanilla sales.
With 32.3 to $71.6 \mathrm{~g} \mathrm{~d}^{-1}$ per person, the average intake of fat was slightly below the recommended daily quantity of fat for a physically active person (Institute of Medicine 2005) but was higher than the fat intake of HHs surveyed by Golden et al. (2019). One reason might be the sudden increase of fat intake at the end of the year (November-December; see Fig. 7) through the consumption of fat-rich food. Most likely this was due to the high purchasing power from (vanilla) sales combined with week-long Christmas and New Year festivities that are traditionally related to high meat consumption.

The average protein intake per person was relatively high compared to the rest of Madagascar (Golden et al. 2019; WFP and ONN 2016). This could have been driven by the high consumption of ASF protein that exceeded the average supply of animal protein reported for Madagascar $\left(10 \mathrm{~g} \mathrm{~d}^{-1}\right.$ per person, average of 2011-2013, FAOStat 2019, http://www.fao.org/ faostat/en/\#country/129). In fact, sufficient protein intakes are regularly reported for Malagasy diets but vary considerably across regions (Lapenu et al. 2000). Here, surveyed HHs might have had enough purchasing power - due to vanilla income and therefore regularly consumed high quality foods such as ASF and fish. Furthermore, many vanilla farmers keep livestock themselves (Kunz et al. 2020).

On the contrary, the intake of micronutrients (vitamin A and vitamin E) was greatly deficient throughout the year due to insufficient consumption of nutrient-dense foods (vegetables and fruits). The intake of vitamin A by the sampled HHs did not even meet half of the recommend daily intake of Retinol Activity Equivalents (RAE), which is about $900 \mu \mathrm{g}$ $\mathrm{d}^{-1}$ per person (Trumbo et al. 2001). Deficiency in vitamin A is leading to a reduced vision, impaired immunity and children are less likely to recover from common diseases such as diarrhea. In fact, deficiency in vitamin A, followed by calcium deficiency, is one of the most frequent micronutrient deficiencies in Madagascar (Shiratori and Nishide 2018). About 62\% of the average vitamin A intake of the sampled HHs came from fruits and vegetables and only 29\% from ASF (mostly eggs, yoghurt and milk). Fruits and vegetables are essential sources of vitamin A, however, their availability is highly seasonal (see Fig. 5). Since the SAVA region is isolated from other parts of Madagascar, food transportation is expensive and risky. In addition, the continuously high vanilla prices lead to regional inflation, which impacted living costs and local food prices, in particular of nutritious foods (Hänke and Fairtrade International 2019; Llopis et al. 2020). In consequence, the population predominately relied on starchy staple foods of lower nutritional value, which cost less per calorie but put humans at risk of micronutrient deficiencies (Darmon and Drewnowski 2015). A study by Save the Children (2015) in the SAVA region reported that the cost of a nutritious diet is approximately 3.6 times greater than that of the "energy only diet", which is largely adopted by the local vanilla farming population. Despite the key role of starch as the major source 
of calories in human nutrition, consumption of large quantities is linked to diseases such as diabetes (Bao 2017; Edwards and Warren 2019). A common image in the SAVA region are "rice bellies", particularly among children, that are caused by a lack of protein, mineral and vitamin consumption and indicate severe malnourishment also known as "Kwashiorkor" (Kimutai et al. 2009).

While food access is an important factor for an adequate diet, other factors such as food choice, cultural habits, education and awareness about nutritious foods are also important (Chakona and Shackleton 2019; Wardle et al. 2000). Although vegetables and other greens are consumed in Madagascar, their quality and the quantity balance between food groups are mostly based on habits and cultural choices, and they can vary across regions. For instance, according to our HDDS results based on the FAO thresholds (Wiesmann et al. 2009), almost all HHs consumed a sufficiently diverse diet. However, Malagasy dishes are mainly composed of rice and very small quantities of non-starch foods such as tomatoes, onions, beans or meat. Thus, even if a diet is classified as "diverse" through HDDS - since many food groups are consumed on a weekly but not daily basis - the nutritional value of the food consumed is not necessarily represented accurately by this indicator as quantities are not considered.

Regarding food choices, factors such as food costs, availability, health concerns (cleanness of food), and energy density (starchy foods) were more important than diet diversity for the rural population in Madagascar (Farris et al. 2019; Rakotosamimanana et al. 2014). Likewise, another Malagasy study argued that, although greens such as cassava leaves are perceived as having negative effects on health, they are widely consumed because they are cheap, enjoyed by children and satiating (Rakotosamimanana et al. 2015).

Concerning nutritional knowledge, a study conducted in the Malagasy Anosy Region showed that women possessed only very basic nutritional knowledge, which constitutes an important barrier to improved nutrition (Dell 2009). Indeed, enhancing nutritional knowledge and awareness, especially among women, improves the quality of family diets and in particular children's nutrient intakes (Alkerwi et al. 2015). Hence, promoting region-specific nutritional programs that especially target women and children could significantly improve the quality of Malagasy diets.

\subsection{Seasonal variation}

Seasonality is playing an important role in the availability of foods (quantity and quality) in Madagascar, mainly due to its highly variable zonal climates with major implications for food production systems (Harvey et al. 2014). The lean season in Madagascar generally occurs at the beginning of the rainy season (around November/December) before the rice harvest and extends until March (Harvey et al. 2014), during which calorie consumption falls and composition of food consumed also changes as HHs reduce rice consumption and substitute secondary foods such as root and tubers (Dostie et al. 2002). The nutritional effects of seasonal variation in food availability are particularly important in contexts where people's consumption depends on their agricultural production (Ravaoarisoa et al. 2019).

In the results of our time series analysis, decreasing fluctuations of FSI were observed just before the end of the year (i.e. November) until January, with a stronger decrease for contracted HHs compared with non-contracted HHs. This strong effect of the lean season on contracted vanilla $\mathrm{HHs}$ may come from the fact that those HHs mainly produce vanilla (see Table 2), i.e., their main income is earned once a year at the end of the vanilla season (June to August), and they may lack other income sources that might buffer expenses throughout the year (Zhu 2018). Furthermore, noncontracted HHs were producing more rice than the contracted HHs (see Table 2). Therefore, contracted HHs might be more sensitive to seasonal changes in food availability and/or price (lean period, shocks) than non-contracted HHs.

In general, the values of most measured nutrient intakes (energy, protein, vitamins and fat) and food security indicators (FSI, HDDS, FCS) were highest in December as compared with other months. This is in accordance with the findings of Golden et al. (2019) who were also studying the NE part of Madagascar and reported a general increase of nutrient intake in the hot/rainy season (around December). The increase in energy intake at the end of the year is predominantly linked to the harvest and availability of paddy rice in November/ December, while the festive season (Christmas, New Year) only provides a secondary explanation.

A general decrease in food security indicators and in nutrient intakes was observed during August until October, followed by a small drop in March, but the extent largely differed between indicators: FSI, energy, carbohydrate, protein and fat intake showed similar trends and were more stable compared to the intake of micronutrients (vitamins $\mathrm{A}$ and $\mathrm{E}$ ). This similarity may come from the fact that all of these categories point to macronutrients and their intake is often associated with energy supply (Institute of Medicine 2005; Tremblay et al. 1991).

In our study, the consumption of rice was stable across the year while that of roots and tubers, fruits and vegetables varied substantially (see Fig. 7). Rice is the most important food for the Malagasy population and is socio-culturally strongly linked to Malagasy beliefs (Hume 2005). However, although dietary preferences and consumption patterns are influenced by cultural values, inequalities persist between regions, whereby rice production, $\mathrm{HH}$ income and purchasing power also play an important role (Herrador et al. 2015). In the second part of Madagascar's lean season (January and February, in some regions until April) a strong decrease in calorie consumption of HHs was observed by Dostie et al. (2002). In our sample, this 
second decrease was also observed for the indicators FSI and energy intake, but with only a slight decrease around March. Here, the relatively stable rice consumption of our sample HHs seems to have prevented a major subsistence food shortage and the occurrence of a severe "lean season" phenomenon. This might be due to the high production of rice in the region, especially in the Andapa basin termed "rice bowl" of $\mathrm{NE}$ Madagascar (Laney and Turner 2015), but could also be linked to the improved purchasing power the vanilla farming HHs.

In contrast, the variation in micronutrient intake (vitamin A and E) was more pronounced and showed several low peaks. The main reasons are the variation in rainfall, temperature, agricultural cycles and associated food availability in the SAVA region. For instance, a strong drop in vitamin A intake was observed in October, whereby the decrease started already in August, the coolest month in this region but also across Madagascar. Vitamin A-rich foods are mostly leafy vegetables and fruits and their availability is highly seasonal (Ravaoarisoa et al. 2018). Another key factor affecting local food availability in Madagascar are climate shocks such as cyclones and floods, causing physical damage to crop fields, vanilla plantations, roads, and houses. The SAVA region bears the highest risk for natural disasters in Madagascar (Le Bellec 2018). In 2017 the cyclone ENAWO destroyed vanilla and agricultural fields and left many people homeless (Probst et al. 2017). This had an impact on vanilla and crop production in the area and might have affected food availability and access even during the study period.

\subsection{Factors influencing food security and consumption of ASF}

Studies analyzing factors that determine rural HHs' food security in developing countries point to land holdings, livestock ownership, education, $\mathrm{HH}$ income from agriculture, soil fertility and off-farm income as the most important factors (Gebre-Selassie 2005; Mango et al. 2014; Negatu 2004). In our analysis, the most significant factors influencing FSI were $\mathrm{HH}$ size and cash income from rice. On the contrary, consumption of ASF was determined by the number of income sources as well as overall cash crop income. These findings are in line with other studies conducted in Madagascar (Assefa 2018; Noromiarilanto et al. 2016; Ravaoarisoa et al. 2018), as well as in other African countries (Nkomoki et al. 2019; Shone et al. 2017), where HH size, cash crop income and "other income sources" were among the factors significantly influencing the food security of rural HHs.

Larger HH sizes are often associated with a negative food security status as it increases food expenditures and competition for limited resources (De Cock et al. 2013; Ahmed et al. 2017), which is in line with our findings. Also, in rural Madagascar there is a trend of "the larger the $\mathrm{HH}$, the poorer the HH" (World Bank 2017). Nevertheless, although HH size was negatively associated with FSI, larger HHs might offer more agricultural labor force if the $\mathrm{HH}$ members are in an agriculturally productive age.

Subsistence agriculture is often discussed as an important factor for $\mathrm{HH}$ food security as it helps to mitigate high food price inflation and other shocks (Sibhatu and Qaim 2017). While most of the surveyed HHs spent a great share of their total food expenses on rice, those who were able to produce and sell surplus rice were significantly more food secure (FSI), particularly when considering that the SAVA region currently faces a high inflation of food costs through the vanilla boom (Llopis et al. 2020). In a recent survey in Madagascar's vanilla triangle, about $90 \%$ of vanilla farmers listed rice as an important subsistence crop and only around $40 \%$ as a cash crop (Hänke et al. 2018, in review). Although some of the vanilla farmers primarily cultivated rice and vanilla was only their second crop in terms of labor and cash invested (Andrianisaina et al. forthcoming), the lower rice production of the contracted HHs compared to the non-contracted HHs might in parts explain their lower food security status. In fact, HHs producing more staple food than they consume were found to be less vulnerable to food price shocks and, consequently, more food secure (de Janvry and Sadoulet 2011).

Consumption of nutritious foods, calories and protein often depends on income in Madagascar (Lapenu et al. 2000), whereby higher income is often linked to higher consumption of protein rich (ASF) foods (Angeles-Agdeppa et al. 2019; Thang and Popkin 2004). This supports the determined importance of income and number of income sources as the prime determinants of ASF consumption in the sampled HHs.

Surprisingly, having a vanilla contract (with buyers and/or exporters) was negatively associated with FSI $(P=0.05)$. According to the initial baseline survey (DTBL) of our research project (Hänke et al. 2018, in review), contracted HHs produce and sell significantly more vanilla, and own larger vanilla plots compared with non-contracted HHs, which was also applying to our sample (see Table 2). This negative association might be due to the fact that income of contracted HHs stems mainly from vanilla, which is highly seasonal, whereas additional compensating incomes are lacking (see Section 4.3). Yet, the vanilla boom lead to a volatile spending practice in the SAVA region (e.g. beer, smartphone, "khat" Catha edulis), where farmers who did not know how to ride a bicycle bought fancy bicycles (Zhu 2018). Thus, vanilla farmers tend to convert vanilla cash quickly into valuable items (houses, solar panels, TVs and motorbikes...), with little consideration for longer-term savings or true investments (ibid). On the other hand, vanilla income was not selected in the final stepwise GLM models, neither for FSI nor for the contribution of ASF protein to household nutrition. Likewise, our results showed that vanilla income between contracted and non-contracted HHs was not significantly different (t-Test, $P=0.091)$. Here, the fact that vanilla income is not significant as distinction between household groups is also an important result for the vanilla sector in the SAVA region, but the underlying reasons need further investigation. 
While inability to equilibrate income and expenditure peaks increases the risk of food insecurity during lean seasons, e.g. in Bangladesh (Khandker 2009), income diversification has been reported to have positive effect on food security (Owusu et al. 2011). As explained earlier, contracted vanilla HHs that own more - and larger - vanilla plots than non-contracted farmers (Hänke et al. 2018, in review) may not dispose of the necessary time, labor or knowledge to diversify their income. Also, given the current high prices, vanilla theft has increased dramatically in the SAVA region (Hänke et al. 2018, in review; Neimark et al. 2019) and many farmers reallocate agricultural labor and substantial amounts of money to protect their harvest (Llopis et al. 2020). In this way, vanilla farmers become increasingly dependent on vanilla and are more vulnerable to shocks such as theft or vanilla price drops. Therefore, it may not per se be the fact of having a vanilla contract that negatively impacts FSI but the effect of associated factors, such as too strong focus on vanilla, no time to invest in other activities, time needed to secure vanilla fields, low subsistence crop production, and lack of additional income during the year.

Although livestock production did not significantly influence food security, animal husbandry is important for income diversification and as a source of high-quality protein. ASF have been described by the World Health Organization as a high-quality nutrient-rich food for children and vital in improving nutrition, food security and health (Adesogan et al. 2020). ASF consumption contributes substantially to diet quality but its limited availability and relatively high price is restricting its consumption in low-income countries like Madagascar (Adesogan et al. 2020; Murphy and Allen 2003). Several studies discussed the importance of meat consumption for an improved diet quality of rural Malagasy people, showing that bushmeat consumption is an important source of protein and vitamin A (Merson et al. 2019; Reuter et al. 2016). In the present study, however, bushmeat consumption did not significantly improve food security of vanilla farming HHs. One reason could be the low share of bushmeat in the consumed foods, which may be linked to our sampling approach (primary forests are far away). On the other hand, improving access to ASF reduces hunting pressure on wild animals (Merson et al. 2019).

\subsection{Limitations of the study}

There are several limitations to the present study that may have influenced the results. First, calculation of the Food Security Index (FSI) and nutrient intakes (per person per day) requires several steps and conversion errors can easily occur (Carletto et al. 2013). For instance, the exact number of persons who shared a meal might sometimes have been different than the initially recorded HH size. The study design did not allow for intra-household comparison of food consumption of individual members or member groups. We assumed that food was shared equally between all family members, depending of course on the members' age and gender. However, there is evidence, e.g. from India, that this is not necessarily the case (Fiedler and Yadav 2017). Nevertheless, the amount of foods lost and consumed away from home was considered low in our case, because when working in the fields people are cooking and eating their own food in the evening (this option was represented in the pictograms) or they come back home for the lunch.

Furthermore, the conversion from local units (e.g. pieces) to international units (e.g. kilogram) might have introduced an over- or underestimation of food intake as local units sometimes show large variability, and limiting our sample to $\mathrm{HHs}$ located not more $10 \mathrm{~km}$ away from primary and secondary roads may challenge the representativeness of HHs living in very remote areas in the SAVA region. Kunz et al. (2020) estimated that around $10-20 \%$ of the local population was excluded from the DTBS, which also applies to subsequent surveys relying on its stratification approach. This bias may have been reinforced by the fact that we compared contracted to non-contacted vanilla farmers, and vanilla companies purposefully decide on where to source vanilla (Hänke et al. 2018, in review). Hence, as stated above, some results such as the low consumption of bushmeat, might be linked to this sampling bias. Including HHs located far from main and secondary roads (i.e. at forest edges), and a more detailed intrahousehold analysis of food consumption would have been needed to reduce eventual errors and bias in the results.

Beyond being location specific, the insights from this study are also time-specific: The survey focused on vanilla producing households and was conducted during a period of exceptionaly high vanilla prices (Cooks Vanilla 2019; Appendix Fig. 9). Not all of its results might therefore be representative for periods of e.g. low level prices of this commodity. Moreover, one needs to be careful with respect to comparing our results to other parts of the country and keep the outstanding context in mind.

\subsection{Policy dimensions and recommendations}

This section addresses our main findings and their implications for policies and programs to improve nutrition and strengthen the food security of vanilla faming HHs in the SAVA region. Despite a huge agricultural potential of the SAVA region and a high availability of cash from vanilla, the nutritional status of many vanilla farming $\mathrm{HHs}$ is alarming. Also, despite numerous social and environmental programs established in the region (Save The Children 2019; Symrise 2018; Unilever 2016), there is insufficient focus on diet quality and food security of (vanilla) farming $\mathrm{HHs}$, which both clearly need improvement. Although there is no "silver bullet" to fight food insecurity and achieve "zero hunger" for (vanilla) farmers, several tools and mechanisms could improve local diets and food security in the SAVA region - and thus contribute to achieving the Sustainable Development Goal 2 (UNDP 2018). 
Unvaried diets primarily based on rice, and insufficient consumption of nutritious food is a major reason for the poor nutritional value of the HHs' diets. In Madagascar, the rice hull is cracked and only the white seed is eaten. Accordingly, the rice seed contains exclusively carbohydrates while minerals and vitamins are lost (USDA 2019). Local people claim "If you don't eat rice three times a day, you are poor", which points to the strong beliefs and customs linked to rice in the Malagasy culture. There is an urgent need for nutritional education targeting specific population groups, especially women who are mainly involved in meal preparations; reaching out to vulnerable groups like young (school) children would also be advantageous. In this regard, increasing awareness of "balanced and healthy nutritional diets" among women and youth early in the educational system would help to improve their nutritional knowledge (Farris et al. 2019; Rakotosamimanana et al. 2014), and improve infant diets and growth in rural areas (Paul et al. 2012; Shi and Zhang 2011). Healthier dietary habits established during childhood may be carried into adulthood (Blaylock 1999), which may also reduce the risk of malnutrition and diet-related diseases in adults. In the SAVA region, such education should include specific "eating habit messages" that target cultural barriers in food choices and promote the consumption of locally available nutritious foods, such as local varieties of fruits and vegetables. Likewise, many nutritious local varieties of beans and lentils exist and can be easily stored. At the same time, hill rice cultivation (tavy) is one of the main driving forces for deforestation in NE Madagascar, particularly through slash-and-burn agriculture (Styger et al. 2007; Hänke et al. 2018, in review; Zaehringer et al. 2016). Compared to vanilla agroforests, paddy fields and hill rice plots accommodate weak levels of biodiversity (Martin et al. 2020a; Martin et al. 2020b). To avoid such negative impacts of rice cultivation, the system of rice intensification (SRI) could be an option for hill rice fields, as this approach showed encouraging ecological and agronomic outcomes (Stoop et al. 2002). Since SRI has low adoption rates in Madagascar, mainly explained by high labour costs (Moser and Barrett 2003) and limited availability of organic inputs, respective interventions have to take these constraints as well as local perspectives into account. On the other hand, other starchy foods such as roots and tubers could be promoted - they are cheaper than rice, can be harvested throughout the year and do not depend that much on rain as is the case for rice or maize (Dostie et al. 2002; Serpantié and Toillier 2007). By promoting a diversified basket of starchy staples, rural development programs could join forces with conservationists to both improve human nutrition and protect the unique regional biodiversity.

However, nutritional campaigns alone will not be sufficient to improve food security of the vanilla farmers. Policy makers, local institutions, vanilla actors and those involved in nutritional programs need to ensure that efforts are made to enhance farmers' resilience towards food insecurity. Today many farmers are in a highly vulnerable situation as they almost exclusively rely on vanilla sales. If prices drop, they will earn very little cash income and have no means to fall back on subsistence crops. As income from vanilla is strictly seasonal, HHs need to secure their income and balance their expenses throughout the year in order to access food even during lean season and in times of shocks. Also, many farmers who produce large quantities of rice lack storing facilities and therefore often sell all rice directly after harvest when prices are low (Andrianisaina et al. forthcoming). Some development agencies and NGOs have started to establish "farmer business schools" in the SAVA region, which show promising results according to our observations. However, scientists who have worked in the region point to the fact that rice fields are considered secure assets and constitute a socially-sanctioned substitute banking system (Laney and Turner 2015). Therefore, training in judicious management of financial resources and at the same time considering endogenous factors (i.e. cultural and social relations) may have a positive impact on food security.

Moreover, in times of high vanilla prices, theft and crime are key constraints to vanilla farmers. Theft pressure prevents vanilla farming HHs to invest more cash and labour in subsistence crops or other activities that may improve their livelihoods. Also, theft and crime drive planting decisions (Andriatsitohaina et al. 2020) and negatively affect the quality and yield of vanilla as well as the farmers' food security, which may develop into a vicious cycle. Therefore, policy makers and local communities should join forces to develop strategies that reduce crime and theft, enforce law and protect the local population.

\section{Conclusions}

This study sheds light on the nutritional situation of vanilla farming households in the SAVA region and disentangles the multiple factors determining their food security and diet quality. While the vanilla boom has improved the livelihoods of many vanilla farmers, the majority of the HHs does not meet the daily energy requirements for a healthy and a productive life. In particular vitamin A and vitamin E consumption is greatly deficient, which is a threat to children's health. Major threats to food security in the SAVA region are a rice-centered local food culture and high food price inflation. Due to high vanilla prices, many farmers exclusively rely on cash income through vanilla, which enhances their vulnerability to food insecurity. Diversification of income earning activities through subsistence crop farming or livestock production can enhance diet diversity and food security but is hampered by labor availability. Regional programs that raise awareness, improve nutritional education of women and youth and promote farming practices for high-quality local foods should be paired with policy interventions that reduce vanilla-related crime and theft. 


\section{Appendix 1}

Fig. 9 Average world market vanilla prices 1999-2019 (black vanilla). Source: https://www. cooksvanilla.com/vanilla-marketreport-a-spaghetti-westernseptember-2019/

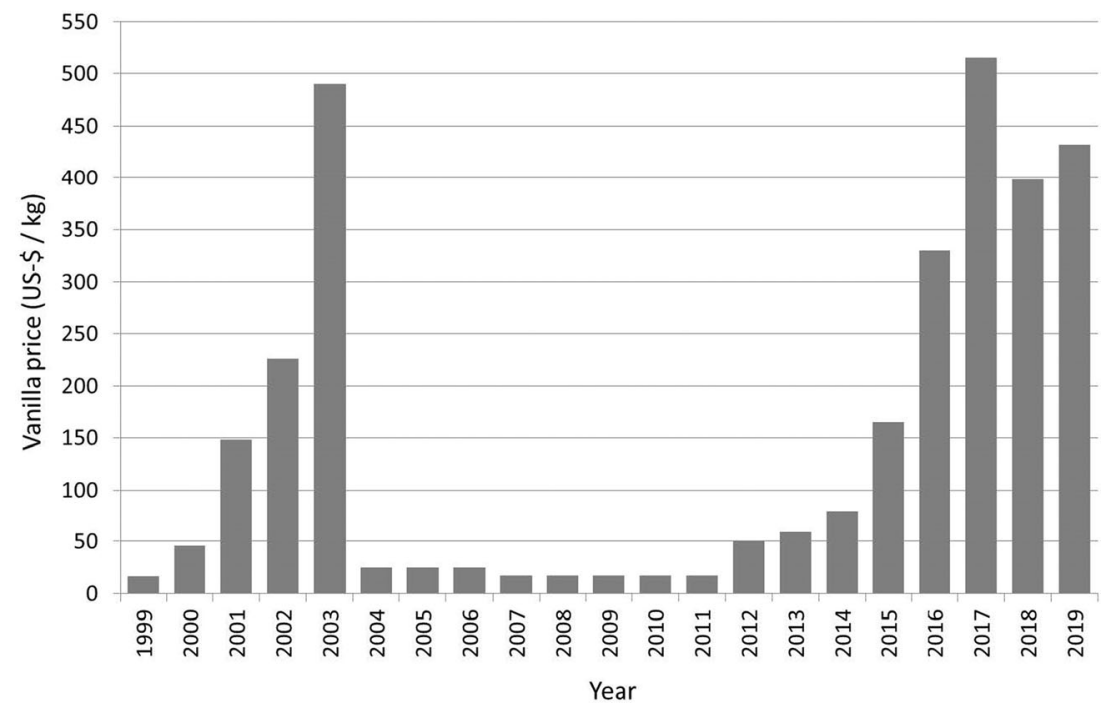

\section{Appendix 2}

Table 4 Village and household selection for the 12-month food consumption survey in the SAVA region, NE Madagascar

\begin{tabular}{|c|c|c|c|c|c|}
\hline \multicolumn{3}{|c|}{ Villages with vanilla contracts } & \multicolumn{3}{|c|}{ Villages without vanilla contracts } \\
\hline $\mathrm{N}$ Inhabitants & $\mathrm{N}$ Villages & N Households & $\mathrm{N}$ Inhabitants & N Villages & N Households \\
\hline $0-1000$ & 1 & 14 & $0-1000$ & 1 & 14 \\
\hline $1001-2000$ & 1 & 14 & $1001-2000$ & 1 & 14 \\
\hline $2001-3000$ & 1 & 14 & $2001-3000$ & 1 & 14 \\
\hline $3001-4000$ & 1 & 14 & $3001-4000$ & 1 & 14 \\
\hline$>4000$ & 1 & 14 & $>4000$ & 1 & 14 \\
\hline Sum & 5 & 70 & Sum & 5 & 70 \\
\hline
\end{tabular}


1000

Andriamparany J.N. et al.

Appendix 3

Table 5 Pictograms used for the food consumption survey in the SAVA region, NE Madagascar

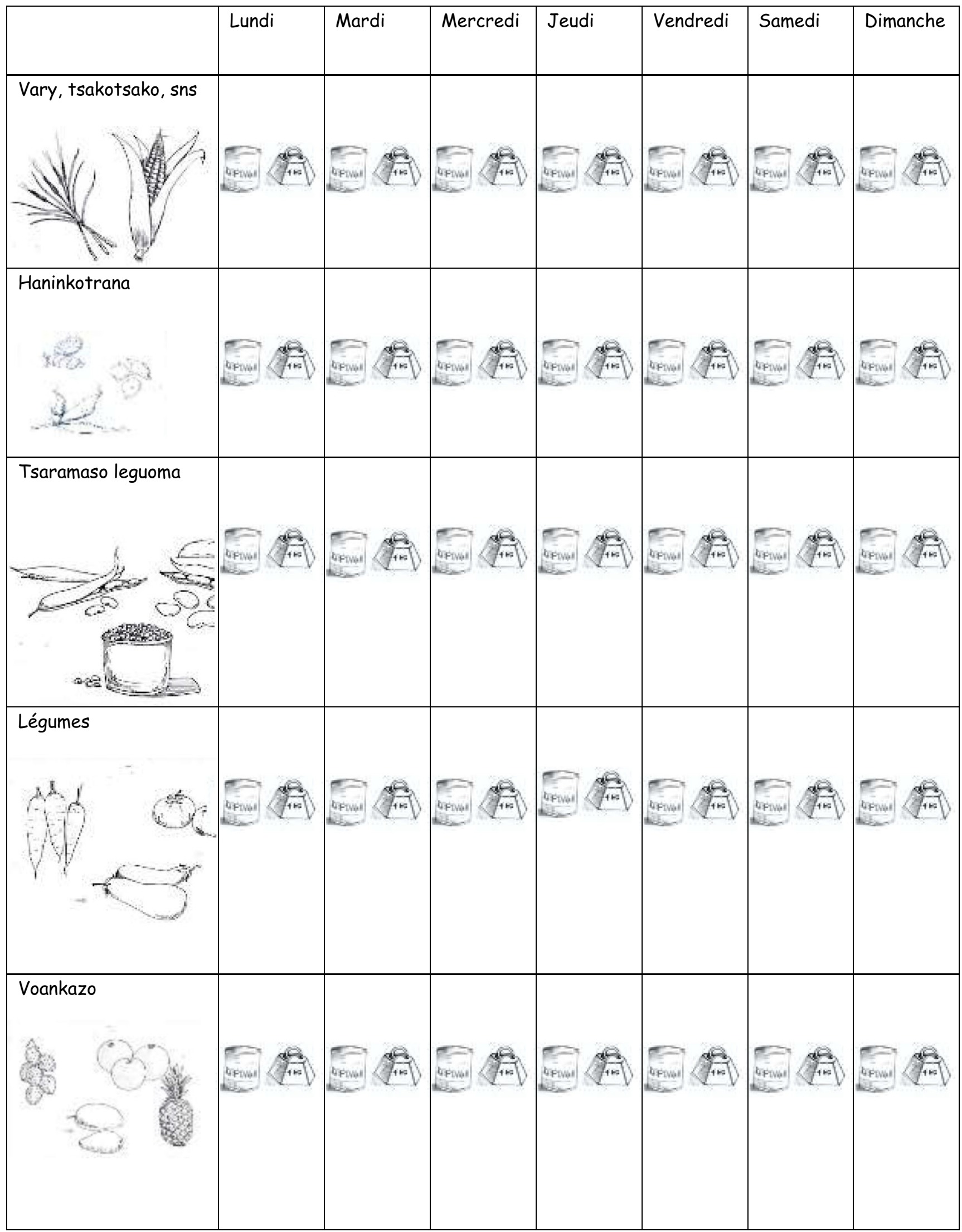

Springer 


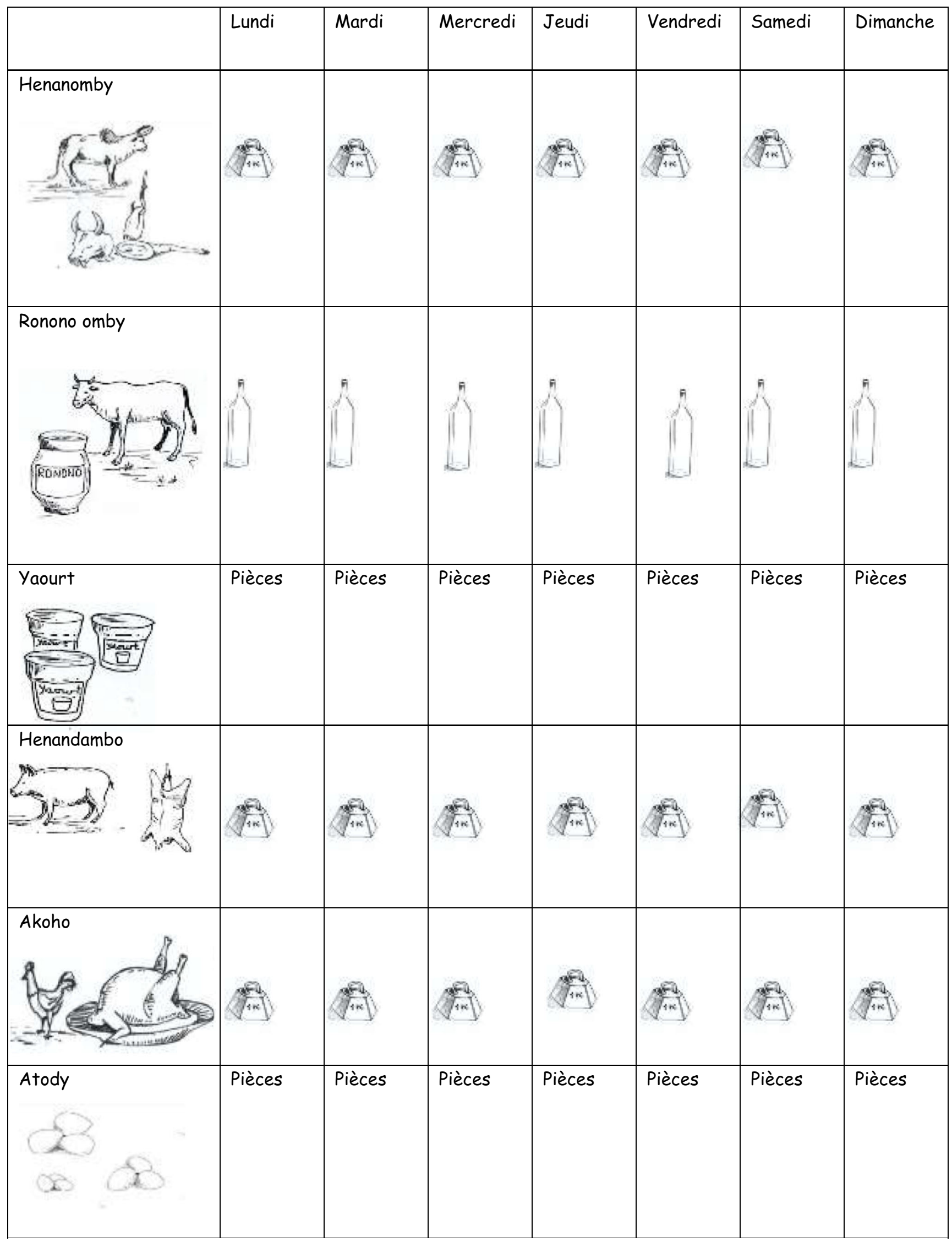


1002

Andriamparany J.N. et al.

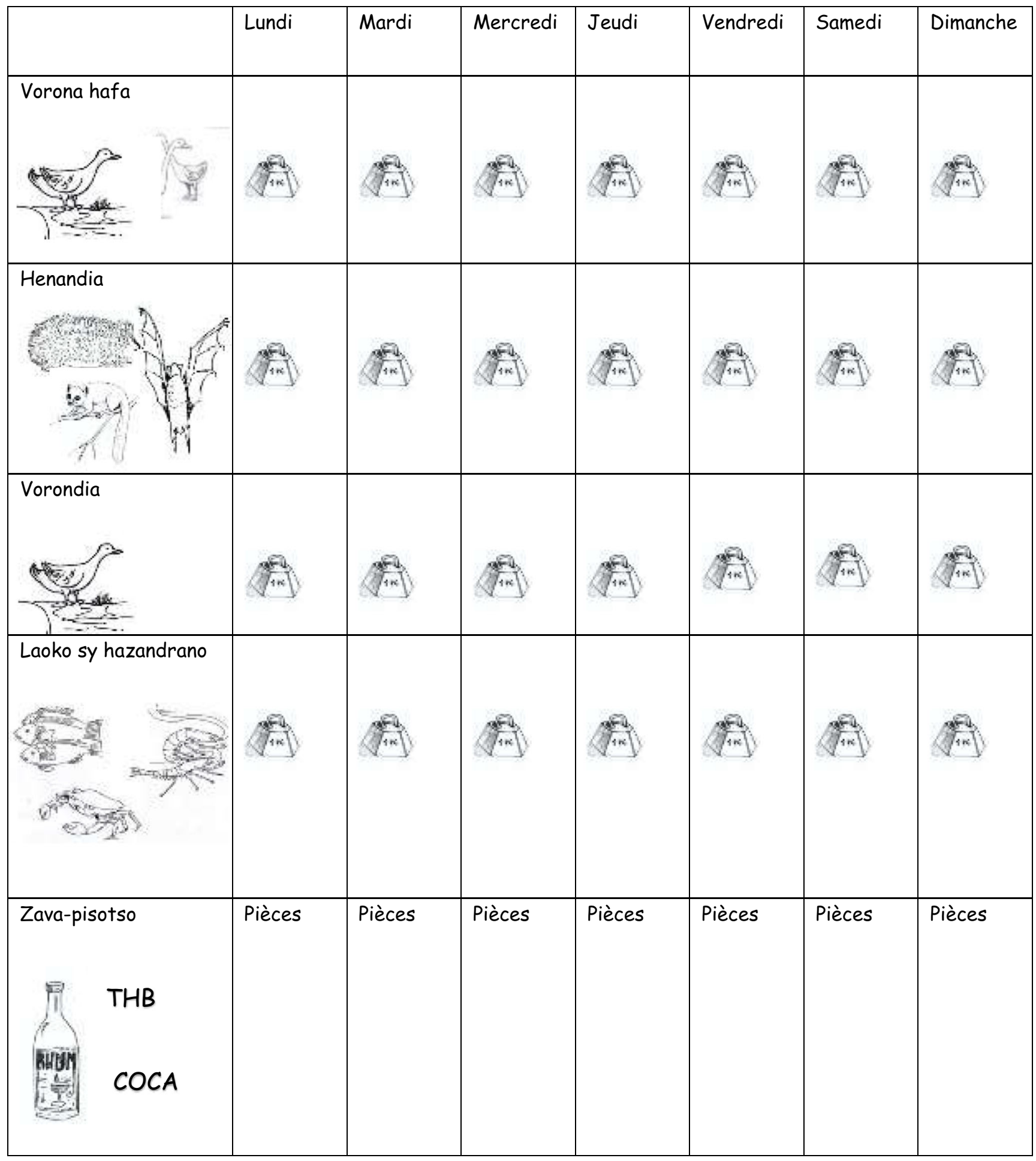

Springer 


\section{Appendix 4}

Table 6 Adult equivalent reference scale for different gender and age groups to assess household food security in the SAVA region, NE Madagascar

\begin{tabular}{ll}
\hline Gender (age) group & Equivalent scale \\
\hline Men ( $\geq 18$ years) & 1 \\
Women $(\geq 18$ years $)$ & 0.86 \\
Girls and boys $(<18$ years $)$ & 0.78 \\
\hline
\end{tabular}

\section{Appendix 5}

Table 7 Nutrient composition of food items used in the calculation of nutrient intakes of the 104 households in the SAVA region, NE Madagascar. List of food items are from food security (July 2018-June 2019) and food seasonality (September 2019) surveys. All nutritional information is for $100 \mathrm{~g}$ of each food

\begin{tabular}{|c|c|c|c|c|c|c|c|c|}
\hline Food group & Food (common name) & Food (local name) & $\begin{array}{l}\text { Energy } \\
\text { (kcal) }\end{array}$ & $\begin{array}{l}\text { Protein } \\
(\mathrm{g})\end{array}$ & $\begin{array}{l}\text { Fat } \\
(\mathrm{g})\end{array}$ & $\begin{array}{l}\text { Carbohydrates } \\
\text { (g) }\end{array}$ & $\begin{array}{l}\text { Vit A (retinol } \\
\text { equivalents, } \mu \mathrm{g} \text { ) }\end{array}$ & $\begin{array}{l}\text { Vit E } \\
(\mathrm{mg})\end{array}$ \\
\hline Cereal & Rice & Brown rice, boiled & 135 & 3.0 & 0.80 & 28.4 & 0 & 0.23 \\
\hline Cereal & Rice & Riz rouge & 141 & 3.4 & 0.69 & 28.2 & 0 & 0.10 \\
\hline Cereal & Maize & Tsakotsako legny & 96 & 3.5 & 1.50 & 20.9 & 13 & 0.09 \\
\hline $\begin{array}{l}\text { Roots \& } \\
\text { Tubers }\end{array}$ & Cassava & Mahogo & 160 & 1.4 & 0.30 & 38.0 & 0 & 0.19 \\
\hline $\begin{array}{l}\text { Roots \& } \\
\text { Tubers }\end{array}$ & Yams & Ovy be (Majola) & 134 & 2.0 & 0.20 & 28.9 & 2 & 0.49 \\
\hline $\begin{array}{l}\text { Roots \& } \\
\text { Tubers }\end{array}$ & Wild yams & Ovy dia/Ovy & 85.3 & 2.7 & 0.20 & 28.9 & 2 & 0.49 \\
\hline $\begin{array}{l}\text { Roots \& } \\
\text { Tubers }\end{array}$ & Sweet potato & Tsomanga & 87 & 1.1 & 0.10 & 24.3 & 787 & 5.00 \\
\hline $\begin{array}{l}\text { Roots \& } \\
\text { Tubers }\end{array}$ & Taro & Sahogno mandady & 142 & 0.5 & 0.10 & 34.6 & 4 & 2.40 \\
\hline $\begin{array}{l}\text { Roots \& } \\
\text { Tubers }\end{array}$ & Taro & Sahogno & 294 & 1.9 & 0.20 & 26.5 & 3 & 2.4 \\
\hline $\begin{array}{l}\text { Roots \& } \\
\quad \text { Tubers }\end{array}$ & Breadfruit & Soanambo & 103 & 1.1 & 0.20 & 27.1 & 4 & 1.00 \\
\hline $\begin{array}{l}\text { Roots \& } \\
\text { Tubers }\end{array}$ & Banana plantain & Fontsy & 156 & 1.2 & 0.30 & 31.2 & 83 & 0.21 \\
\hline Pulses & Peanuts beans & Pistaches & 333 & 15.0 & 22.01 & 21.2 & 0 & 2.58 \\
\hline Pulses & Beans & Haricot & 127 & 8.7 & 0.50 & 22.8 & 0 & 0 \\
\hline Pulses & Cowpeas & Lojo & 137 & 8.6 & 0.50 & 22.3 & 3 & 0.14 \\
\hline Pulses & Lima beans & Gros pois & 115 & 7.8 & 0.38 & 20.8 & 0 & 0.18 \\
\hline Pulses & Mung bean & Tsiasisa & 105 & 7.1 & 0.38 & 19.1 & 1 & 0.15 \\
\hline Vegetables & Tomato & Tomaty & 18 & 0.9 & 0.20 & 3.8 & 42 & 0.54 \\
\hline Vegetables & Palm hearts & Hovotra & 115 & 115.0 & 2.70 & 0.2 & 3 & 0.50 \\
\hline Vegetables & Cucumber & Cocombre & 15 & 15.0 & 0.70 & 0.1 & 5 & 0 \\
\hline Vegetables & Carrots & Karaoty & 41 & 0.9 & 0.20 & 9.6 & 841 & 0.70 \\
\hline Vegetables & Squash vegetables & Daboira & 20 & 0.9 & 0.30 & 4.3 & 29 & 0 \\
\hline Vegetables & Onion & Tongolo & 40 & 1.3 & 0.20 & 9.2 & & \\
\hline Vegetables & Potato & Pomme de terre & 85 & 2.0 & 0.10 & 17.6 & 0 & 0.01 \\
\hline Vegetables & Eggplant & Aubergine & 25 & 1.0 & 0.20 & 5.9 & 0 & 1.00 \\
\hline Vegetables & Cabbage & Laisoa & 25 & 1.9 & 0.30 & 5.0 & 8 & 0.04 \\
\hline Vegetables & General term for greens & Anana & 37 & 3.4 & 0.38 & 6.5 & 249 & 0.92 \\
\hline Fruits & Jackfuit & Ampalibe & 94 & 1.5 & 0.30 & 24.0 & 15 & 0 \\
\hline
\end{tabular}


Table 7 (continued)

\begin{tabular}{|c|c|c|c|c|c|c|c|c|}
\hline Food group & Food (common name) & Food (local name) & $\begin{array}{l}\text { Energy } \\
\text { (kcal) }\end{array}$ & $\begin{array}{l}\text { Protein } \\
(\mathrm{g})\end{array}$ & $\begin{array}{l}\text { Fat } \\
(\mathrm{g})\end{array}$ & $\begin{array}{l}\text { Carbohydrates } \\
(\mathrm{g})\end{array}$ & $\begin{array}{l}\text { Vit A (retinol } \\
\text { equivalents, } \mu \mathrm{g} \text { ) }\end{array}$ & $\begin{array}{l}\text { Vit E } \\
(\mathrm{mg})\end{array}$ \\
\hline Fruits & Corossol & Corossol & 66 & 1.0 & 0.30 & 24.0 & 0 & 0.10 \\
\hline Fruits & Guava & Gavobe & 57 & 1.1 & 0.40 & 15.3 & 60 & 0.70 \\
\hline Fruits & Lychee & Letchi & 78 & 0.8 & 0.40 & 16.9 & 0 & 0.07 \\
\hline Fruits & Asian apple & Makoba & 45 & 0.6 & 0.20 & 10.1 & 1 & 0.12 \\
\hline Fruits & Pineapple & Mananasy & 48 & 0.5 & 0.10 & 12.6 & 3 & 0 \\
\hline Fruits & Mango & Manga & 65 & 0.5 & 0.30 & 17.0 & 168 & 0 \\
\hline Fruits & Papaya & Vapaza & 39 & 0.6 & 0.10 & 9.8 & 135 & 1.00 \\
\hline Fruits & Orange & Raonjy & 47 & 0.9 & 0.10 & 11.8 & 8 & 0 \\
\hline Fruits & June plume & Sakoana & 92 & 1.2 & 6.12 & 10.2 & 24 & 0.96 \\
\hline Fruits & Watermelon & Vojabo & 22 & 0.4 & 0.20 & 7.6 & 20 & 0 \\
\hline Fruits & Avocado & Zavoka & 160 & 2.0 & 14.70 & 8.5 & 7 & 2.10 \\
\hline Fruits & Banana & Akondro & 89 & 1.1 & 0.30 & 23.0 & 3 & 0.10 \\
\hline Meat_Beef & Beef & Henanomby & 209 & 36.2 & 7.20 & 0 & 0 & 0.29 \\
\hline Dairy_Milk & Milk & Ronono & 60 & 3.2 & 3.30 & 4.5 & 28 & 0.10 \\
\hline $\begin{array}{l}\text { Dairy_- } \\
\quad \text { Yoghurt }\end{array}$ & Yoghurt & Yogourt & 59 & 10.0 & 0.40 & 4.4 & 0 & 0.01 \\
\hline Meat_Porc & Pork & Henandambo & 550 & 28.9 & 52.70 & 0 & 0 & 0.10 \\
\hline Poultry & Chicken & Akoho & 268 & 22.0 & 20 & 0 & 35 & 0.22 \\
\hline Eggs & Chicken eggs & Atody akoho & 245 & 11.8 & 21.60 & 1.0 & 114 & 1.30 \\
\hline Eggs & Duck eggs & Atody & 185 & 12.8 & 13.77 & 1.45 & 194 & 1.34 \\
\hline Poultry & Duck & Drakidraky & 337 & 18.9 & 28.35 & 0 & 63 & 0.70 \\
\hline Meat_wild & Greater hedgehog tenrec & Sokina & 113 & 14.4 & 4.38 & 0 & 0 & 0.38 \\
\hline Meat_wild & Tailless tenrec & Trandraka & 107 & 15.0 & 4.38 & 0 & 0 & 0.38 \\
\hline Meat_wild & $\begin{array}{l}\text { Lemur (White-headed } \\
\text { lemur) }\end{array}$ & Gidro & 105 & 15.6 & 4.38 & 0 & 0 & 0.38 \\
\hline Meat_wild & $\begin{array}{l}\text { Lemur (Eastern woolly } \\
\text { lemur) }\end{array}$ & Gidro & 139 & 23.1 & 4.38 & 0 & 0 & 0.38 \\
\hline Meat_wild & Aye-aye & Aye-aye & 105 & 15.6 & 4.38 & 0 & 0 & 0.38 \\
\hline Poultry_wild & Passerine type bird & Fody & 225 & 21.5 & 15.08 & 0 & 50 & 0.43 \\
\hline Poultry_wild & Guinea fowl & Akanga & 158 & 23.4 & 6.45 & 0 & 28 & 0.43 \\
\hline Poultry_wild & Lesser vasa parrot & Boeza & 225 & 21.5 & 15.08 & 0 & 50 & 0.43 \\
\hline Poultry_wild & Dove & Tsilengo (Finengo) & 213 & 23.9 & 13 & 0 & 28 & 0.06 \\
\hline Fish & Dried freshwater fish & $\begin{array}{l}\text { Laoko ranomamy } \\
\text { maina }\end{array}$ & 335 & 58.6 & 9.40 & 0 & 0 & 0 \\
\hline Fish & Dried shrimp & $\begin{array}{l}\text { Orana maina } \\
\text { (Makamba) }\end{array}$ & 301 & 55.8 & 2.40 & 13.1 & 5 & 7.30 \\
\hline Fish & Dried saltwater fish & $\begin{array}{l}\text { Laoko ranomasina } \\
\text { maina }\end{array}$ & 368 & 79.8 & 3.20 & 0 & 49 & 4.00 \\
\hline Fish & Freshwater fish & $\begin{array}{l}\text { Laoko ranomamy } \\
\text { legny }\end{array}$ & 84 & 14.8 & 2.30 & 0 & 12 & 2.00 \\
\hline Fish & Saltwater fish & $\begin{array}{l}\text { Laoko ranomasina } \\
\text { legny }\end{array}$ & 98 & 18.1 & 2.40 & 0 & 0 & 0 \\
\hline Fish & Crab & Drakaka & 85 & 13.9 & 0.67 & 0.6 & 18 & 2.00 \\
\hline Beverage & Coca Cola & Coca Cola & 42 & 0 & 0.30 & 10.0 & 0 & 0 \\
\hline Beverage & Soda & Soda & 51 & 0 & 0 & 13.0 & 0 & 0 \\
\hline Beverage & Sprite & Sprite & 40 & 0.1 & 0 & 10.0 & 0 & 0 \\
\hline
\end{tabular}




\section{Appendix 6}

Table 8 Construction of food security indicators

\begin{tabular}{|c|c|c|}
\hline Indicator & $\begin{array}{l}\text { Number of food groups } \\
\text { included in calculation }\end{array}$ & List of food groups included in calculation \\
\hline Food Security Index (FSI) & 16 & $\begin{array}{l}\text { All foods from: Cereal, Roots and tubers, Pulses, Vegetables, Fruits, Beef meat, Porc meat, } \\
\text { Chicken meat, Eggs, Other poultry meat, Wild meat including wild poultry, Fish and } \\
\text { other sea/freshwater products, Beverages }\end{array}$ \\
\hline Food Consumption Score & 7 & $\begin{array}{l}\text { Staples (cereals, roots and tubers), Pulses, Vegetables, Fruits, Meat } \\
\text { (i.e. beef, pig, poultry)/Fish/Eggs, Dairy products, Beverages }\end{array}$ \\
\hline $\begin{array}{l}\text { Household Dietary } \\
\text { Diversity Score } \\
\text { (HDDS) }\end{array}$ & 10 & $\begin{array}{l}\text { Cereals, Roots and tubers, Pulses, Vegetables, Fruits, Dairy, Meat } \\
\text { (red meat and poultry), Eggs, Fish, Beverages }\end{array}$ \\
\hline
\end{tabular}

\section{Appendix 7}

Table 9 Factor reduction with Principal Component Analysis

\begin{tabular}{|c|c|c|c|c|}
\hline \multirow[t]{2}{*}{ Factor groups } & \multicolumn{4}{|c|}{ Component value } \\
\hline & 1 & 2 & 3 & 4 \\
\hline \multicolumn{5}{|l|}{ Household classes } \\
\hline Multidimensional Poverty Index (score) & 0.95 & & & \\
\hline Multidimensional Poverty Index (yes/no) & 0.94 & & & \\
\hline Vanilla contract (yes/no) & & 0.64 & & \\
\hline Household head (Male/Female) & & 0.52 & & \\
\hline \multicolumn{5}{|l|}{ Social status } \\
\hline Age of household's head & -0.76 & & 0.31 & \\
\hline Arrival date & 0.62 & 0.43 & -0.55 & \\
\hline Education & 0.58 & & & \\
\hline Marital status & 0.54 & 0.70 & 0.52 & \\
\hline Religion & 0.30 & -0.66 & & \\
\hline Household size & -0.77 & & 0.52 & \\
\hline \multicolumn{5}{|l|}{ Fields } \\
\hline Number of fields & 0.81 & & & -0.41 \\
\hline Number of crops & 0.47 & 0.58 & 0.34 & -0.49 \\
\hline Rice harvest (daba*) & & 0.64 & 0.57 & \\
\hline Vanilla harvest $(\mathrm{kg})$ & & 0.58 & 0.40 & 0.60 \\
\hline Number of vanilla plots & 0.75 & & & 0.51 \\
\hline Vanilla field (ha) & 0.84 & & -0.36 & \\
\hline Upland rice field (ha) & 0.81 & & & \\
\hline Irrigated rice field (ha) & & -0.67 & 0.70 & \\
\hline Rice field (ha) & 0.62 & -0.54 & 0.52 & \\
\hline Field_size (ha) & 0.93 & -0.30 & & \\
\hline \multicolumn{5}{|l|}{ Income } \\
\hline Cash income (MGA) & 0.73 & 0.39 & & \\
\hline Forest product income (MGA) & -0.31 & 0.72 & & \\
\hline Vanilla income (MGA) & -0.38 & 0.60 & & \\
\hline Rice income (MGA) & & & 0.91 & \\
\hline \multicolumn{5}{|l|}{ Use of forest products } \\
\hline Collect of wild foods (number of species) & 0.92 & & & \\
\hline Use of wild meat (yes/no) & 0.92 & & & \\
\hline \multicolumn{5}{|l|}{ Livestock } \\
\hline TLU & 0.99 & & & \\
\hline Livestock production (yes/no) & 0.97 & & & \\
\hline Number of zebu & 0.96 & & & \\
\hline Number of chicken & & -0.48 & & \\
\hline Number of animal species & 0.95 & & & \\
\hline
\end{tabular}

Automatic selection $>0.3$; the higher the component value, the better the factor for each component; $(*)$ Rice harvest in "daba", a local unit with 1 daba $\approx 15.24 \mathrm{~kg}$; Monetary units (i.e. income factors) are expressed in Malagasy Ariary (MGA) 


\section{Appendix 8}

Table 10 Summary results of times series analysis using ARIMA model for contracted and non-contracted vanilla households in the SAVA region, north-eastern Madagascar

\begin{tabular}{|c|c|c|c|c|c|}
\hline \multirow{2}{*}{$\begin{array}{l}\text { Indices } \\
\text { Model and parameters }\end{array}$} & & \multicolumn{2}{|l|}{ FSI } & \multicolumn{2}{|c|}{ Share of ASF_protein in diets } \\
\hline & & Contracted household & Non-contracted household & $\begin{array}{l}\text { Contracted } \\
\text { household }\end{array}$ & Non-contracted household \\
\hline \multicolumn{2}{|l|}{ Model type ARIMA } & $(0,0,0)$ & $(0,0,0)$ & $(0,0,0)$ & $(0,0,0)$ \\
\hline \multicolumn{2}{|l|}{ Coef. } & 0.53 & 0.62 & 20.65 & 16.70 \\
\hline \multicolumn{2}{|l|}{ Std.Error } & 0.02 & 0.02 & 2.26 & 1.55 \\
\hline \multicolumn{2}{|l|}{$(\sigma 2)$} & 0.00 & 0.01 & 66.85 & 31.32 \\
\hline \multicolumn{2}{|l|}{ Log Likelihood } & 15.60 & 14.10 & -41.72 & -37.17 \\
\hline \multicolumn{2}{|l|}{ AIC } & -27.20 & -24.19 & 87.44 & 78.34 \\
\hline \multicolumn{2}{|l|}{ BIC } & -26.23 & -23.22 & 88.41 & 79.31 \\
\hline \multicolumn{2}{|l|}{ Z-value } & 27.60 & 28.96 & 9.14 & 10.80 \\
\hline \multicolumn{2}{|l|}{$\operatorname{Pr}(>|z|)$} & $\mathrm{p}=<0.001$ & $\mathrm{p}=<0.001$ & $\mathrm{p}=<0.001$ & $\mathrm{p}=<0.001$ \\
\hline \multirow[t]{3}{*}{ Ljung-Box Test, lags $=4$} & Q-stat & 3.56 & 1.05 & 0.88 & 2.16 \\
\hline & DF & 3.00 & 3.00 & 3.00 & 3.00 \\
\hline & $\mathrm{p}$ & 0.31 & 0.79 & 0.83 & 0.54 \\
\hline \multicolumn{2}{|l|}{ MAE } & 0.06 & 0.06 & 0.06 & 6.73 \\
\hline \multicolumn{2}{|l|}{ RMSE } & 0.07 & 0.07 & 0.07 & 7.83 \\
\hline \multicolumn{2}{|l|}{ MannKendall } & 0.54 & 0.54 & 0.37 & 0.95 \\
\hline
\end{tabular}

Number of points used for each model is equal to 84 (i.e. 7 days per month during 12 months) 

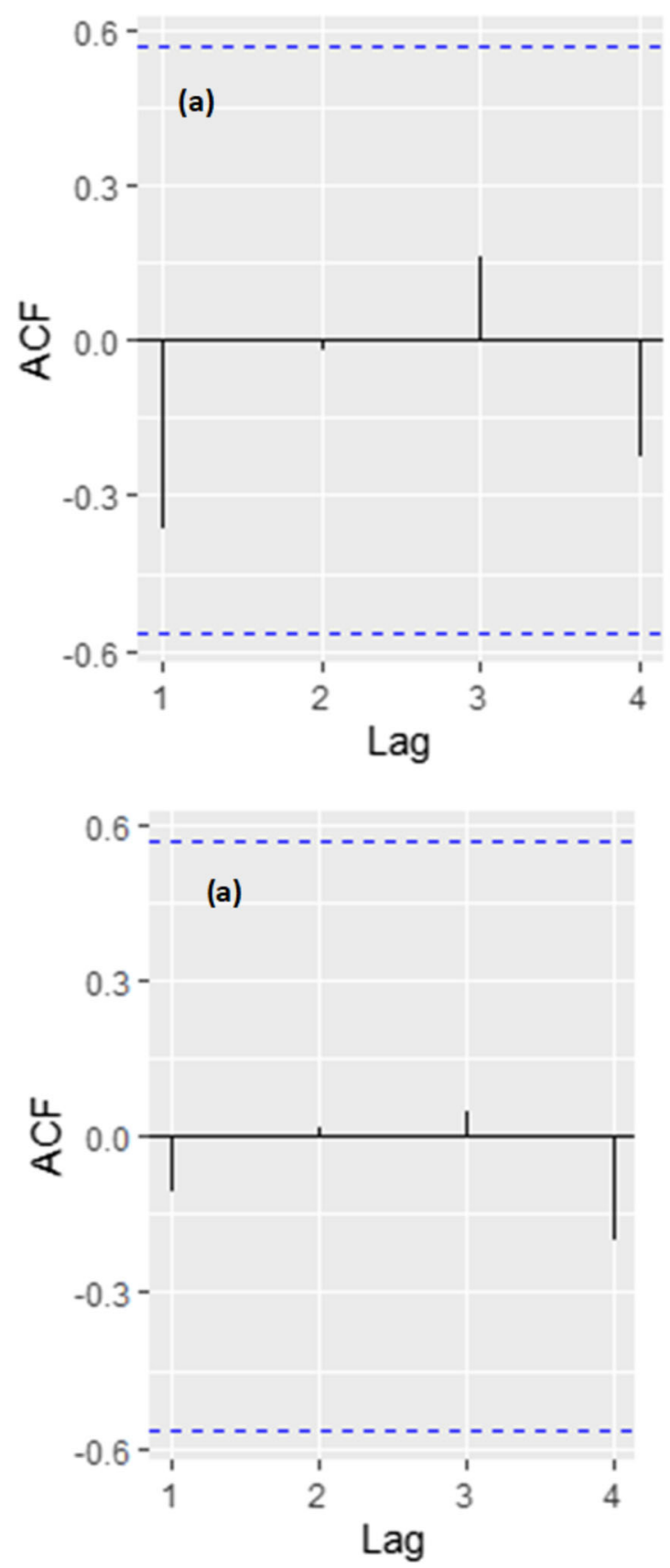

Fig. 10 ACF (Auto Correlation Function) plots of residuals, all from ARIMA models $(0,0,0)$ with non-zero mean, for vanilla contracted $(\mathrm{a}=$ FSI, $b=$ share of ASF_protein) and for non-contracted households $(\mathrm{c}=$

Acknowledgements We are grateful to Fenohaja Babarezoto for providing administrative and logistic support and to Joel and Doria for their assistance in data collection and translation. Likewise, we thank Fanilo Andrisaina for sharing data with us. Our special thanks go to all households who participated in the surveys and the Diversity Turn project team for their support.

Authors' contributions ES and $\mathrm{HH}$ conceived the idea for the study. $\mathrm{HH}$ organized and supervised the food survey. The study analysis was designed by JNA, HH and ES. JNA led data analysis and interpretation of the data, supported by HH and ES. JNA and HH drafted the initial paper.

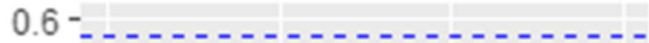

(b)

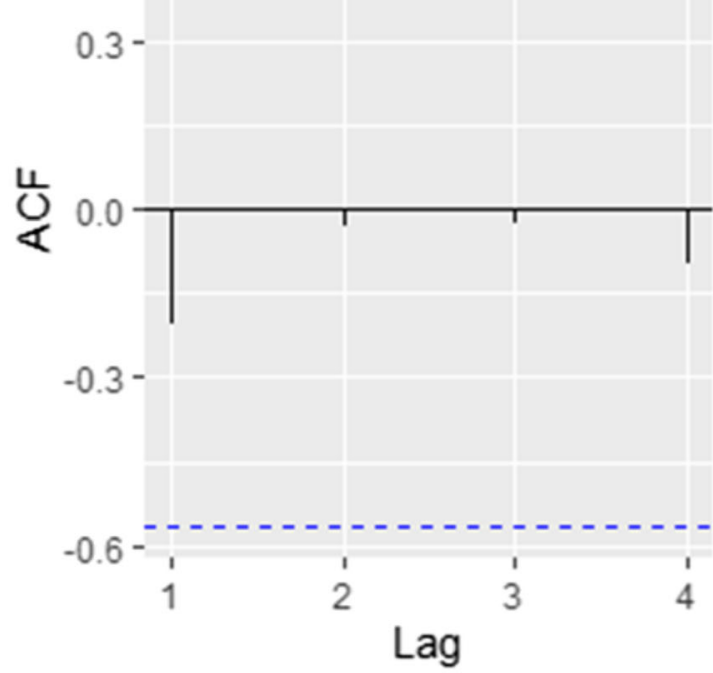

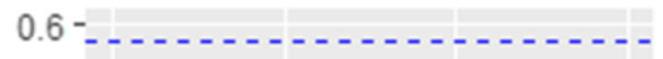

(d)

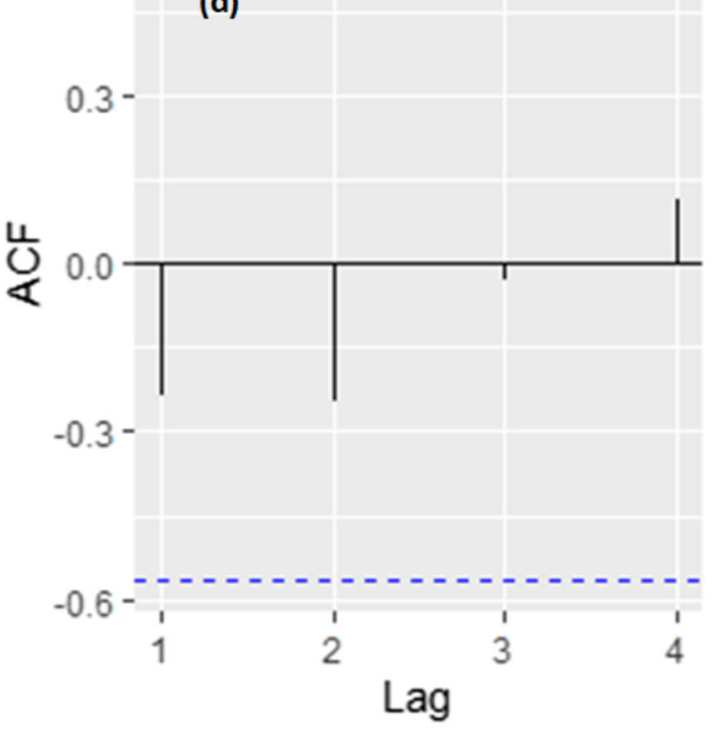

FSI, $d=$ share of ASF protein). Survey period $=12$ months from between July 2018 and June 2019

All authors contributed to the content and critical revision of the paper and agreed to submit the paper for publication.

Availability of data and material Detailed information and data may be shared with interested scientists upon written request.

Funding Open Access funding enabled and organized by Projekt DEAL. This study was part of the project Diversity Turn in Land Use Science (https://www.uni-goettingen.de/en/529181.html), funded by the program 
line "Niedersächsiches Vorab" of Volkswagen Foundation Hanover, Germany (grant number: 11-76251-99-35/13 (ZN3119)).

\section{Declarations}

Human right statement and informed consent All followed procedures were in accordance with the ethical standards of the responsible committee on human experimentation (institutional and national) and with the Helsinki Declaration of 1964 and its later amendments. Informed consent was obtained from all participants for being included in the survey study.

Animal rights This manuscript does not refer to any study with animals.

Conflicts of interests/competing interests Jessica N. Andriamparany, Hendrik Hänke, and Eva Schlecht declare that they have not conflict of interest.

Open Access This article is licensed under a Creative Commons Attribution 4.0 International License, which permits use, sharing, adaptation, distribution and reproduction in any medium or format, as long as you give appropriate credit to the original author(s) and the source, provide a link to the Creative Commons licence, and indicate if changes were made. The images or other third party material in this article are included in the article's Creative Commons licence, unless indicated otherwise in a credit line to the material. If material is not included in the article's Creative Commons licence and your intended use is not permitted by statutory regulation or exceeds the permitted use, you will need to obtain permission directly from the copyright holder. To view a copy of this licence, visit http://creativecommons.org/licenses/by/4.0/.

\section{References}

Achterbosch, T. J., van Berkum, S., Meijerink, G. W., Asbreuk, H., \& Oudendag, D. A. (2014). Cash crops and food security; Contributions to income, livelihood risk and agricultural innovation. LEI report 2014-015. Wageningen: LEI Wageningen UR, University \& Research Centre.

Adesogan, A. T., Havelaar, A. H., McKune, S. L., Eilittä. M., \& Dahl, G. E. (2020). Animal source foods: Sustainability problem or malnutrition and sustainability solution? Perspective matters. Global Food Security, 25, 100325.

Ahmed, U. I., Ying, L., Bashir, M. K., Abid, M., \& Zulfiqar, F. (2017). Status and determinants of small farming households' food security and role of market access in enhancing food security in rural Pakistan. PloS One, 12(10), e0185466.

Alkerwi, A., Sauvageot, N., Malan, L., Shivappa, N., \& Hébert, J. R. (2015). Association between nutritional awareness and diet quality: Evidence from the observation of cardiovascular risk factors in Luxembourg (ORISCAV-LUX) study. Nutrients, 7(4), 2823-2838.

Alkire, S., \& Housseini, B. (2014). Multidimensional poverty in SubSaharan Africa: Levels and trends, working paper 81. Oxford: University of Oxford. https://ophi.org.uk/wp-multidimensionalpoverty-in-sub-saharan-africa-levels-and-trends/

Andrianisaina, F., Hänke, H., \& Barkmann, J. (forthcoming). Longitudinal Survey. SAVA region. Madagascar: Diversity Turn Project.

Andriatsitohaina, R. N. N., Celio, E., Llopis, J. C., Rabemananjara, Z. H., Ramamonjisoa, B. S., \& Grêt-Regamey, A. (2020). Participatory Bayesian network modeling to understand driving factors of landuse change decisions: Insights from two case studies in northeast Madagascar. Journal of Land Use Science, 15(1), 69-90.
Angeles-Agdeppa, I., Lenighan, Y. M., Jacquier, E. F., Toledo, M. B., \& Capanzana, M. V. (2019). The impact of wealth status on food intake patterns in Filipino school-aged children and adolescents. Nutrients, 11(12), 2910.

Arimond, M., Wiesmann, D., Becquey, E., Carriquiry, A., Daniels, M., Deitchler, M., et al. (2011). Dietary diversity as a measure of the micronutrient adequacy of women's diets in resource-poor areas: Summary of results from five sites. Washington, DC: FANTA-2 Bridge, FHI, 360.

Assefa, B. A. (2018). Factors Influencing the Food Security of Smallholder Farmers in Madagascar. Master thesis. Minneapolis: University of Minnesota.

Bao, J. (2017). Starch in health and disease. Starch-Stärke, 69(7-8), 1770076 .

Barrett, C. B., Reardon, T., \& Webb, P. (2001). Nonfarm income diversification and household livelihood strategies in rural Africa: Concepts, dynamics, and policy implications. Food Policy, 26(4), 315-331.

Blaylock, J. (1999). Maternal nutrition knowledge and children's diet quality and nutrient intakes: Food assistance and nutrition research report no.1. Washington DC: US Department of Agriculture (USDA): Economic Research Service.

Burchi, F., \& de Muro, P. (2016). From food availability to nutritional capabilities: Advancing food security analysis. Food Policy, 60, $10-19$.

Calcagno, V., \& de Mazancourt, C. (2010). Glmulti: An R package for easy automated model selection with (generalized) linear models. Journal of Statistical Software, 34(12), 1-29.

Carletto, C., Zezza, A., \& Banerjee, R. (2013). Towards better measurement of household food security: Harmonizing indicators and the role of household surveys. Global Food Security, 2(1), 30-40.

Chakona, G., \& Shackleton, C. (2019). Food taboos and cultural beliefs influence food choice and dietary preferences among pregnant women in the eastern cape, South Africa. Nutrients, 11(11), 2668.

Coates, J. (2013). Build it back better: Deconstructing food security for improved measurement and action. Global Food Security, 2(3), 188-194.

Cooks Vanilla (2019). VANILLA MARKET REPORT: September 2019. https://ophi.org.uk/wp-multidimensional-poverty-in-subsaharan-africa-levels-and-trends/. Accessed 08.03.2021.

Core Team, R. (2013). R: A language and environment for statistical computing. Vienna: R Foundation for Statistical Computing.

CREAM (2014). Monographie de la Région SAVA. Centre de Recherches, d'Études et d'appui à l'Analyse Eco-nomique à Madagascar. Antananarivo, Madagascar. https://www.pseau.org/ outils/ouvrages/mg_mef_monographie-region-sava_2014.pdf.

Darmon, N., \& Drewnowski, A. (2015). Contribution of food prices and diet cost to socioeconomic disparities in diet quality and health: A systematic review and analysis. Nutrition Reviews, 73(10), 643660.

De Cock, N., D’Haese, M., Vink, N., Van Rooyen, C. J., Staelens, L., Schönfeldt, H. C., \& D'Haese, L. (2013). Food security in rural areas of Limpopo province, South Africa. Food Security, 5(2), 269-282.

de Janvry, A., \& Sadoulet, E. (2011). Subsistence farming as a safety net for food-price shocks. Development in Practice, 21(4-5), 472-480.

Dell, E. M. (2009). Women's nutritional and hygienic knowledge in Madagascar: a qualitative health needs assessment of the Anosy region. Master thesis. British Columbia: Faculty of Health Sciences-Simon Fraser University.

Dostie, B., Haggblade, S., \& Randriamamonjy, J. (2002). Seasonal poverty in Madagascar: Magnitude and solutions. Food Policy, 27(5-6), 493-518.

Edwards, C. H., \& Warren, F. J. (2019). Starchy foods: Human nutrition and public health. In Interdisciplinary approaches to food digestion (pp. 277-290). New York: Springer. 
Etea, B. G., Zhou, D., Abebe, K. A., \& Sedebo, D. A. (2019). Household income diversification and food security: Evidence from rural and semi-urban areas in Ethiopia. Sustainability, 11(12), 3232.

FAO. (1996). Rome Declaration on World Food Security and World Food Summit Plan of Action: World food summit 13-17 November 1996. Rome: Food and Agriculture Organization of the United Nations.

FAO. (2011). Guidelines for measuring household and individual dietary diversity. Rome: Food and Agricultural Organization of the United Nations Retrieved from http://www.fao.org/3/a-i1983e.pdf.

FAO. (2013). Proceedings of the International Scientific Symposium on Food and Nutrition Security information: from Valid Measurement to Effective Decision Making. Rome, 17-19 January 2012. Rome: Food and Agriculture Organization of the United Nations.

FAO and UPDR (2000). Analyse Diagnostic de la Filière Riz a Madagascar. Rapport Provisoire. FAO TCP/MAG/8821. Antananarivo Madagascar. https://www.maep.gov.mg/communication/wp-content/ uploads/sites/2/2014/06/filiere_riz_est.pdf.

FAO, IFAD, UNICEF, WFP and WHO. (2019). The State of Food Security and Nutrition in the World 2019: Safeguarding against economic slowdowns and downturns. FAO licence: CC BY-NC-SA 3.0 IGO. Rome, Italy: Food and Agriculture Organization of the United Nations.

Farris, A, R., Misyak, S., O'Keefe, K., VanSicklin, L., \& Porton, I. (2019). Understanding the drivers of food choice and barriers to diet diversity in Madagascar. Journal of Hunger \& Environmental Nutrition, 1-13. https://doi.org/10.1080/19320248.19322019. 11566110.

Fiedler, J. L., \& Yadav, S. (2017). How can we better capture food away from home? Lessons from India's linking person-level meal and household-level food data. Food Policy, 72, 81-93.

FPSRAG. (2015). Potentially important food plants of Madagascar: Food plant solutions field guide - Madagascar. Evanston: Food Plant Solutions Rotarian Action Group Retrieved from https:// foodplantsolutions.org/wp-content/uploads/2018/10/PotentiallyImportant-Food-Plants-of-Madagascar-Draft-V1.pdf.

Gebre-Selassie, S. (Ed.). (2005). Poverty and food security in Ethiopia: Some evidences from Wollo. In Proceedings of the second International Conference on the Ethiopian Economy, Vol II. Addis Ababa: Ethiopian Economic Association.

Golden, C. D., Vaitla, B., Ravaoliny, L., Vonona, M. A., Anjaranirina, E. G., Randriamady, H. J., Glahn, R. P., Guth, S. E., Fernald, L. C. H., \& Myers, S. S. (2019). Seasonal trends of nutrient intake in rainforest communities of North-Eastern Madagascar. Public Health Nutrition, 22, 2200-2209.

Hänke, H., \& Barkmann, J. (2017). Insurance function of livestock, farmers coping capacity with crop failure in southwestern Madagascar. World Development, 96, 264-275.

Hänke, H., \& Fairtrade International. (2019). Living income reference Price for Vanilla from Uganda and Madagascar: Full report. Bonn: Fairtrade International Retrieved from https://files.fairtrade. net/publications/Fairtrade_Vanilla_LivingIncomeRefPrice_ fullreport.pdf.

Hänke, H., Barkmann, J., Blum, L., Franke, Y., Martin, D. A., Niens, J., et al. (2018). Socio-economic, land use and value chain perspectives on vanilla farming in the SAVA Region (north-eastern Madagascar). The Diversity Turn Baseline Study (DTBS). July 2019 edition. Discussion paper 1806. Goettingen: Diversity Turn in Land Use Science.

Hänke, H., Blum, L, \& Barkmann, J. (in review). Benefits and determinants of contract farming participation in vanilla value chains, evidence from Madagascar. Journal of Development Studies.

Harvey, C. A., Rakotobe, Z. L., Rao, N. S., Dave, R., Razafimahatratra, H., Rabarijohn, R. H., et al. (2014). Extreme vulnerability of smallholder farmers to agricultural risks and climate change in
Madagascar. Philosophical transactions of the Royal Society of London. Series B, Biological sciences, 369, 20130089.

Headey, D., \& Ecker, O. (2013). Rethinking the measurement of food security: From first principles to best practice. Food security, 5(3), 327-343.

Herrador, Z., Perez-Formigo, J., Sordo, L., Gadisa, E., Moreno, J., Benito, A., Aseffa, A., \& Custodio, E. (2015). Low dietary diversity and intake of animal source foods among school aged children in Libo Kemkem and Fogera districts, Ethiopia. PLoS One, 10(7), e0133435.

Hirvonen, K., Taffesse, A. S., \& Hassen, I. W. (2016). Seasonality and household diets in Ethiopia. Public Health Nutrition, 19(10), $1723-1730$

Huang, J., Nie, F., \& Bi, J. (Eds (2015). Comparison of food consumption score (FCS) and calorie intake indicators to measure food security. In Proceedings of the 2015 International Conference on Social Science, Education Management and Sports Education: Advances in Social Science, Education and Humanities Research retrieved from https://doi.org/10.2991/ssemse-15.2015.296 . Paris, France: Atlantis Press.

Hume, D. W. (2005). Agriculture in Madagascar: Conservation and cultural meanings of rice. PhD Thesis. Storrs, Unites States: University of Connecticut.

ILO. (2011). Etat des lieux du travail des enfants dans la fillière vanille dans la région de la SAVA. Antananarivo: International Labour Organisation of the United Nations Retrieved from http://www.ilo. org/wcmsp5/groups/public/\%2D\%2D-africa/\%2D\%2D-ro-addis_ ababa/\%2D\%2D-ilo-antananarivo/documents/publication/wcms 520913.pdf.

INDEEX Project. (2018). Data4Diets: Building Blocks for Diet-related Food Security Analysis. https://inddex.nutrition.tufts.edu/ data4diets. Accessed 27 January 2020.

Institute of Medicine. (2005). Dietary reference intakes for energy, carbohydrate, fiber, fat, fatty acids, cholesterol, protein, and amino acids. Washington, DC: National Academies Press Washington, DC.

Jahnke, H, E., Tacher, G., Keil, P. \& Rojat, D. (1988). Livestock production in tropical Africa with special reference to the tsetse-affected zone. In Livestock production in tsetse-affected areas of Africa (pp. 3-21). Proceedings of a meeting held by the international livestock Centre for Africa (ILCA) and the International Laboratory for Research on animal diseases (ILRAD), November 23-27, 1987, Nairobi, Kenya: ILCA/ILRAD.

Jones, A. D., Ngure, F. M., Pelto, G., \& Young, S. L. (2013). What are we assessing when we measure food security? A compendium and review of current metrics. Advances in Nutrition, 4(5), 481-505.

Kennedy, G., Ballard, T., \& Dop, M. C. (2011). Guidelines for measuring household and individual dietary diversity. Rome: Food and Agriculture Organization of the United Nations.

Khandker, S, R. (2009). Poverty and income seasonality in Bangladesh. Policy research working paper no. WPS 4923. Washington, DC: The World Bank. https://openknowledge.worldbank.org/handle/ 10986/4114

Kimutai, D., Maleche-Obimbo, E., Kamenwa, R., \& Murila, F. (2009). Hypo-phosphataemia in children under five years with kwashiorkor and marasmic kwashiorkor. East African Medical Journal, 86(7).

Kunz, S., Hänke, H., \& Schlecht, E. (2020). Income diversification through animal husbandry for smallholder Vanilla farmers in Madagascar. Journal of Agriculture and Rural Development in the Tropics and Subtropics, 121(1), 63-75.

Laney, R., \& Turner, B. L. (2015). The persistence of self-provisioning among smallholder farmers in Northeast Madagascar. Human Ecology, 43(6), 811-826.

Lapenu, C., Zeller, M., \& Ralison, E. (2000). Nutritional status and caloric and protein consumption. In Minten, B. \& Zeller, M. (Ed.), Beyond market liberalization: welfare, income generation and 
environmental sustainability in rural Madagascar (pp. 183-207). Aldershot: UK.

Le Bellec, A. (2018). North-eastern Madagascar and cyclone Enawo. In The Hugo Observatory of the University of Liège (Ed), The State of Environmental Migration (pp. 11-34). Lièges: Presses Universitaires de Liège.

Leung, W, T, W. (1968). Food composition table for use in Africa: US Department of Health, education, and welfare, Public Health Service. http://www.fao.org/3/X6877E/X6877E00.htm. Accessed 18 December 2019.

Llopis, J. C., Diebold, C. L., Schneider, F., Harimalala, P. C., Patrick, L., Messerli, P., et al. (2020). Capabilities under Telecoupling: Human well-being between cash crops and protected areas in north-eastern Madagascar. Frontiers in Sustainable Food Systems, 3, 1010.

MacLean, W, C., \& Warwick, P. (2003). Food Energy: Methods of Analysis and Conversion Factors: Report of a Technical Workshop no. 77, 3-6 December 2002. ISSN 0254-4725. Rome, Italy: Food and Agriculture Organization of the Unites States. Retrieved from http://www.fao.org/uploads/media/FAO 2003 Food Energy 02.pdf

Mango, N., Zamasiya, B., Makate, C., Nyikahadzoi, K., \& Siziba, S. (2014). Factors influencing household food security among smallholder farmers in the Mudzi district of Zimbabwe. Development Southern Africa, 31(4), 625-640.

Martin, D. A., Osen, K., Grass, I., Hölscher, D., Tscharntke, T., Wurz, A., \& Kreft, H. (2020). Land-use history determines ecosystem services and conservation value in tropical agroforestry. Conservation Letters, 13(5), e12740.

Martin, D. A., Andriafanomezantsoa, R., Dröge, S., Osen, K., Rakotomalala, E., Wurz, A., ... \& Kreft, H. (2021). Bird diversity and endemism along a land-use gradient in Madagascar: The conservation value of vanilla agroforests. Biotropica, 53(1), 179-190.

Maxwell, D., Coates, J., \& Vaitla, B. (2013). How do different indicators of household food security compare? Empirical evidence from Tigray. Medford, USA: Feinstein international Center, Tufts University. Http://Fic.Tufts.Edu/assets/different-indicators-ofHFS.Pdf.

Merson, S. D., Dollar, L. J., Johnson, P. J., \& Macdonald, D. W. (2019). Poverty not taste drives the consumption of protected species in Madagascar. Biodiversity and Conservation, 28(13), 3669-3689.

Mishra, A. K., Kumar, A., Joshi, P. K., \& D'Souza, A. (2018). Production risks, risk preference and contract farming: Impact on food security in India. Applied Economic Perspectives and Policy, 40(3), 353-378.

Moser, C. M., \& Barrett, C. B. (2003). The disappointing adoption dynamics of a yield-increasing, low external-input technology: The case of SRI in Madagascar. Agricultural Systems, 76(3), $1085-1100$

Murphy, S. P., \& Allen, L. H. (2003). Nutritional importance of animal source foods. The Journal of Nutrition, 133(11), 3932S-3935S.

Naser, K., \& Peel, M. J. (1998). An exploratory study of the impact of intervening variables on student performance in a principles of accounting course. Accounting Education, 7(3), 209-223.

Negatu, W. (2004). Reasons for food insecurity of farm households in south Wollo, Ethiopia: Explanations at grassroots. Madison, Wisconsin: BASIS CRSP (collaborative research support program, Department of Agricultural and Applied Economics, University of Wisconsin-Madison.

Neimark, B., Osterhoudt, S., Blum, L., \& Healy, T. (2019). Mob justice and 'The civilized commodity'. The Journal of Peasant Studies, 1-20. https://doi.org/10.1080/03066150.2019.1680543

Neudert, R., Goetter, J. F., Andriamparany, J. N., \& Rakotoarisoa, M. (2015). Income diversification, wealth, education and well-being in rural South-Western Madagascar: Results from the Mahafaly region. Development Southern Africa, 32(6), 758-784.
Nkomoki, W., Bavorová, M., \& Banout, J. (2019). Factors associated with household food security in Zambia. Sustainability, 11(9), 2715.

Noromiarilanto, F., Brinkmann, K., Faramalala, M. H., \& Buerkert, A. (2016). Assessment of food self-sufficiency in smallholder farming systems of South-Western Madagascar using survey and remote sensing data. Agricultural Systems, 149, 139-149.

Owusu, V., Abdulai, A., \& Abdul-Rahman, S. (2011). Non-farm work and food security among farm households in northern Ghana. Food Policy, 36(2), 108-118.

Paul, K. H., Muti, M., Chasekwa, B., Mbuya, M. N. N., Madzima, R. C., Humphrey, J. H., \& Stoltzfus, R. J. (2012). Complementary feeding messages that target cultural barriers enhance both the use of lipidbased nutrient supplements and underlying feeding practices to improve infant diets in rural Zimbabwe. Maternal \& Child Nutrition, $8(2), 225-238$

Pimpin, L., Kranz, S., Liu, E., Shulkin, M., Karageorgou, D., Miller, V., Fawzi, W., Duggan, C., Webb, P., \& Mozaffarian, D. (2019). Effects of animal protein supplementation of mothers, preterm infants, and term infants on growth outcomes in childhood: A systematic review and meta-analysis of randomized trials. The American Journal of Clinical Nutrition, 110(2), 410-429.

Probst, P., Proietti, C., Annunziato, A., Paris, S., \& Wania, A. (2017). Tropical cyclone enawo post-event report. Joint Research Centre $(J R C)$. Brussels: The European Commission's Science and Knowledge Service.

Rakotosamimanana, V. R., Arvisenet, G., \& Valentin, D. (2014). Studying the nutritional beliefs and food practices of Malagasy school children parents. A contribution to the understanding of malnutrition in Madagascar. Appetite, 81, 67-75.

Rakotosamimanana, V. R., Valentin, D., \& Arvisenet, G. (2015). How to use local resources to fight malnutrition in Madagascar? A study combining a survey and a consumer test. Appetite, 95, 533-543.

Ravaoarisoa, L., Raherimandimby, H., Rakotonirina, J., Rakotomanga, J. D. D. M., Dramaix, M. W., \& Donnen, P. (2018). Mothers' dietary practices in the Amoron'i mania region Madagascar. The Pan African Medical Journal, 30, 76.

Ravaoarisoa, L., Rakotonirina, J., Randriamanantsaina, L., Rakotomanga, J. D. D. M., Dramaix, M. W., \& Donnen, P. (2019). Food consumption and undernutrition variations among mothers during the post-harvest and lean seasons in Amoron'i mania region, Madagascar. BMC Public Health, 19(1), 1005.

Reuter, K. E., Randell, H., Wills, A. R., \& Sewall, B. J. (2016). The consumption of wild meat in Madagascar: Drivers, popularity and food security. Environmental Conservation, 43(3), 273-283.

Ruel, M. T. (2003). Operationalizing dietary diversity: A review of measurement issues and research priorities. The Journal of Nutrition, 133(11), 3911S-3926S.

Ruel, M. T., Harris, J., \& Cunningham, K. (2012). Measuring dietary quality in developing countries: A review of the usefulness of individual dietary diversity indicators. Chapter 18. In V. R. Preedy (Ed.), Diet quality: An evidence-based approach. New York: Springer.

Save The Children. (2015). A Cost of the Diet analysis in the Sava region of Madagascar. SAVA region (Sambava, Andapa, Antalaha), Madagascar. http://docplayer.net/103995645-A-cost-of-the-dietanalysis-in-the-sava-region-of-madagascar.html. Accessed 19 March 2020.

Save The Children. (2019). Save The Children. 2019. Vanilla for change: Building brighter futures for the next generation of vanilla farmers in Madagascar. https://www.savethechildren.org.uk/about-us/whowe-work-with/corporate-partners/unilever/vanilla-for-change. Accessed 10 February.2020.

Serpantié G., Toillier A. (2007). Dynamiques rurales betsileo à l'origine de la déforestation actuelle. In Serpantié G., Rasolofoharinoro B.M. \& Carrière Stéphanie (Ed.). Transitions agraires, dynamiques écologiques et conservation : le "corridor" RanomafanaAndringitra (Madagascar) : actes du séminaire GEREM (Gestion 
des Espaces Ruraux et Environnement à Madagascar, Antananarivo (MDG). Paris, France, Institut de Recherche pour le développement (IRD).

Shi, L., \& Zhang, J. (2011). Recent evidence of the effectiveness of educational interventions for improving complementary feeding practices in developing countries. Journal of Tropical Pediatrics, 57(2), 91-98.

Shiratori, S., \& Nishide, A. (2018). Micronutrient supply based on the food balance sheet and the prevalence of inadequate intakes in Madagascar. Proceedings of the Nutrition Society, Volume 77, Issue OCE3: Irish Section Meeting, 20-22 June 2018, Targeted approaches to tackling current nutritional issues, 2018, E70. https://doi.org/10.1017/S0029665118000745.

Shone, M., Demissie, T., Yohannes, B., \& Yohannis, M. (2017). Household food insecurity and associated factors in west Abaya district, southern Ethiopia, 2015. Agriculture \& Food Security, $6(1), 2$.

Sibhatu, K. T., \& Qaim, M. (2017). Rural food security, subsistence agriculture, and seasonality. PLoS One, 12(10), e0186406.

Soullier, G., \& Moustier, P. (2018). Impacts of contract farming in domestic grain chains on farmer income and food insecurity. Contrasted evidence from Senegal. Food Policy, 79, 179-198.

Stoop, W. A., Uphoff, N., \& Kassam, A. (2002). A review of agricultural research issues raised by the system of rice intensification (SRI) from Madagascar: Opportunities for improving farming systems for resource-poor farmers. Agricultural Systems, 71(3), 249-274.

Styger, E., Rakotondramasy, H. M., Pfeffer, M. J., Fernandes, E. C. M., \& Bates, D. M. (2007). Influence of slash-and-burn farming practices on fallow succession and land degradation in the rainforest region of Madagascar. Agriculture, Ecosystems and Environment, 119(3-4), 257-269.

SVI. (2019). Join Fairtrade at the 2nd Annual Sweet Smelling Fair in Sambava: News article - 4 Oct 2019. Sustainable Vanilla Initiative (SVI). https://www.idhsustainabletrade.com/news/join-fairtrade-atthe-2nd-annual-sweet-smelling-fair-in-sambava/. Accessed 20 March 2020.

Symrise. (2018). The heart of global vanilla production. https://vanilla. symrise.com/sustainable-cultivation. Accessed 20 March 2020.

Thang, N. M., \& Popkin, B. M. (2004). Patterns of food consumption in Vietnam: Effects on socioeconomic groups during an era of economic growth. European Journal of Clinical Nutrition, 58(1), $145-153$.

Tremblay, A., Lavallee, N., Alméras, N., Allard, L., Després, J.-P., \& Bouchard, C. (1991). Nutritional determinants of the increase in energy intake associated with a high-fat diet. The American Journal of Clinical Nutrition, 53(5), 1134-1137.

Trumbo, P., Yates, A. A., Schlicker, S., \& Poos, M. (2001). Dietary reference intakes: Vitamin a, vitamin $\mathrm{K}$, arsenic, boron, chromium, copper, iodine, iron, manganese, molybdenum, nickel, silicon, vanadium, and zinc. Journal of the Academy of Nutrition and Dietetics, 101(3), 294.

UNDP. (2018). Sustainable development goals, goal 2: Zero hunger. New York: United Nations Development Programme Retrieved from https://www.undp.org/content/undp/en/home/sustainabledevelopment-goals/goal-2-zero-hunger.html. Accessed 06 May 2020.

Unilever. (2016). Unilever, Symrise and GIZ join forces with Save the Children to support vanilla farming communities in Madagascar. https://www.unilever.com/news/press-releases/2016/Unileversupport-vanilla-farming-communities-in-Madagascar.html. Accessed 11 February 2020.

UPDR. (2003). Monographie de la Région du SAVA. In Antananarivo, Madagascar: Ministère de l'agriculture, de l'élevage et de la pêche.
Unité Politique pour le: Développement Rural (UPDR) Retrieved from http:/www.gem-madagascar.com/sites/default/files/Sava.pdf.

USAID Madagascar. (2018). Nutrition profile. Antananarivo: United States Agency for International Development Madagascar https:// www.usaid.gov/sites/default/files/documents/1864/MadagascarNutrition-Profile-Mar2018-508.pdf. Accessed 10 February 2020.

USDA. (2019). USDA food composition databases. Washington DC: US Department of Agriculture (USDA) https://ndb.nal.usda.gov/ndb/ search/list?home=true. Accessed 19 March 2020.

Vhurumuku, E. (2014). Food security indicators. In Integrating Nutrition and Food Security Programming for Emergency response workshop 25-17 February 2014. Nairobi: Food and Agriculture Organization of the United Nations Retrieved from http://www. fao.org/fileadmin/user_upload/food-security-capacity-building/ docs / N utrition/Nairobi Workshop/5. W F P IndicatorsFSandNutIntegration.pdf.

Vieilledent, G., Grinand, C., Rakotomalala, F. A., Ranaivosoa, R., Rakotoarijaona, J.-R., Allnutt, T. F., \& Achard, F. (2018). Combining global tree cover loss data with historical national forest cover maps to look at six decades of deforestation and forest fragmentation in Madagascar. Biological Conservation, 222, 189-119.

Wageindicator. (2020). Living wage series - Madagascar - September 2019 - in Malagasy Ariary, per month. WageIndicator Foundation. https://wageindicator.org/salary/living-wage/madagascar-livingwage-series-september-2019.

Wardle, J., Parmenter, K., \& Waller, J. (2000). Nutrition knowledge and food intake. Appetite, 34(3), 269-275.

Weather Sparks (2020). Average weather at Sambava airport Madagascar. Weather Sparks. https:/weatherspark.com/y/150110/ Average-Weather-at-Sambava-Airport-Madagascar-Year-Round. .

WFP. (2008). Measures of Food Consumption - Harmonizing Methodologies: Interagency Workshop report 9-10 April Rome. Rome, Italy: World Food Program (WFP).

WFP. (2009). Comprehensive food security and vulnerability analysis (CFSVA): World Food Programme. (p. 162). Rome, Italy: World Food Program (WFP), Food Security Analysis Service https:// documents.wfp.org/stellent/groups/public/documents/manual guide proced/wfp203208.pdf? ga=2.209954389.1721141380. 1580120698-195724069.1561406851.

WFP. (2016). Country programme-Madagascar (2015-2019): Standard project report 2016. Antananarivo: World Food Program (WFP).

WFP. (2019). Madagascar country strategic plan (2019-2024). Antananarivo: World Food Program (WFP).

WFP, \& ONN. (2016). Fill the nutrient gap Madagascar: Full report. Antananarivo: World Food Program (WFP).

WFP, \& UNICEF. (2011). Comprehensive Food and Nutrition Security and Vulnerability Analysis $(C F S V A+N)$ : Rural Madagascar. Antananarivo: World Food Program(WFP).

WHO. (2014). World health assembly global nutrition targets 2025: stunting policy brief. Retrieved from. http://www.who.int/ nutrition/topics/globaltargets_stunting_policybrief.pdf. Accessed 15.09.2020.

WHO, \& FAO. (2003). Diet, nutrition and the prevention of chronic diseases. World Health Organisation. Technical report series 916. Geneva: World Health Organization.

Wiesmann, D., Bassett, L., Benson, T., \& Hoddinott, J. (2009). Validation of the world food programme s food consumption score and alternative indicators of household food security. Washington, DC: International Food Policy Research Institute (IFPRI).

Workicho, A., Belachew, T., Feyissa, G. T., Wondafrash, B., Lachat, C., Verstraeten, R., \& Kolsteren, P. (2016). Household dietary diversity and animal source food consumption in Ethiopia: Evidence from the 2011 welfare monitoring survey. BMC Public Health, 16(1), 1192. 
World Bank (2010). Roads Madagascar: Geospatial data. https:// datacatalog.worldbank.org/dataset/roads-madagascar. Accessed 12 March 2020.

World Bank. (2017). Shifting fortunes and enduring poverty in Madagascar. Washington D.C.: World Bank http://documents. worldbank.org/curated/en/413071489776943644/pdf/113582-v2FINAL-PUBLIC-7817-Madagascar-Poverty-Report.pdf.

Zaehringer, J. G., Eckert, S., \& Messerli, P. (2015). Revealing regional deforestation dynamics in north-eastern Madagascar - Insights from multi-temporal land cover change analysis. Land, 4(2), 454-474.

Zaehringer, J. G., Hett, C., Ramamonjisoa, B., \& Messerli, P. (2016). Beyond deforestation monitoring in conservation hotspots: Analysing landscape mosaic dynamics in North-Eastern Madagascar. Applied Geography, 68, 9-19.

Zhu, A. (2018). Hot money, cold beer: Navigating the vanilla and rosewood export economies in northeastern Madagascar. American Ethnologist, 45(2), 253-267.

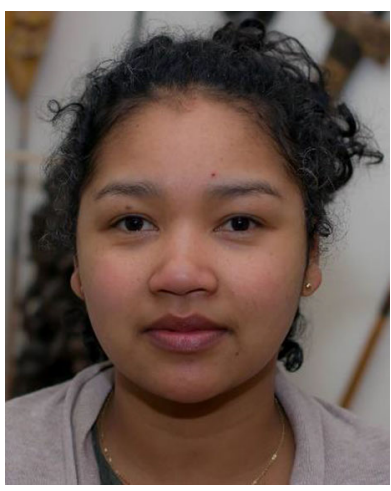

Dr. Jessica N. Andriamparany is currently a researcher in the project "Diversity Turn in Land Use Science", and affiliated to the Section of Animal Husbandry in the Tropics and Subtropics at the University of Goettingen, Germany. Her research interests are in environmental conservation, sustainable agriculture and their implications for people's livelihoods. She has been conducting research on the local use and conservation of edible plants (endemic wild yams, medicinal plants) in Madagascar. She received her Master of Science degree in Plant Biology and Ecology from the University of Antananarivo, Madagascar, and her PhD degree in Agriculture Sciences from the University of Kassel, Section of Organic Plant Production and Agroecosystems Research in the Tropics and Subtropics (OPATS), Germany.

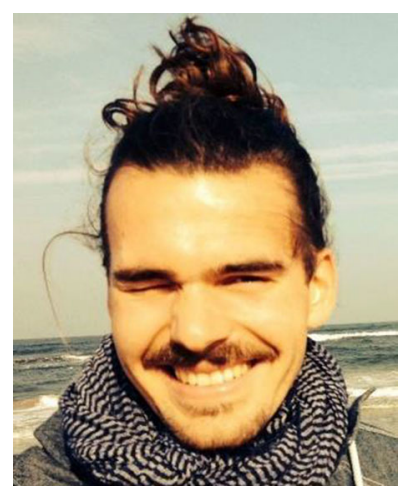

Dr. Hendrik Hänke Hendrik Hänke works as a researcher at the division of Environmentaland Resource Economics, Georg-August-Universität Göttingen. His main research interests are human-environment interactions, food security, rural development and the role of value chains for poverty alleviation. $\mathrm{He}$ was also coordinating the research project "Diversity turn in land use science" in Göttingen and Madagascar. He has extensive experience in field research (Burkina Faso, Cameroon, Uganda \& Morocco), and since $>7$ years he is conducting research in Madagascar. Likewise, Hendrik works regularly as a consultant for organizations such as the GIZ and Fairtrade.

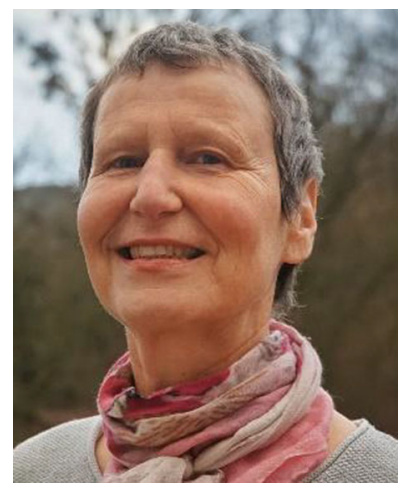

Prof. Dr. Eva Schlecht is heading the Section Animal Husbandry in the Tropics and Subtropics, a joint Chair group at the University of Göttingen and the University of Kassel, Germany. Her research interests are livestock environment interactions, sustainability of livestock systems and the contribution of livestock to rural and urban smallholders' livelihoods. She has extensive research experience in sub-Saharan Africa, the Near and Middle East, and southern and eastern Asia. 